\title{
Hydrologic and Erosion Responses of Sagebrush Steppe Following Juniper Encroachment, Wildfire, and Tree Cutting
}

\author{
Frederick B. Pierson, ${ }^{1}$ C. Jason Williams, ${ }^{2}$ Stuart P. Hardegree, ${ }^{3}$ Patrick E. Clark, ${ }^{4}$ \\ Patrick R. Kormos, ${ }^{5}$ and Osama Z. Al-Hamdan ${ }^{6,7}$
}

\begin{abstract}
Authors are ${ }^{1}$ Research Leader and Supervisory Research Hydrologist, ${ }^{2}$ Hydrologist, ${ }^{3}$ Research Plant Physiologist, ${ }^{4}$ Rangeland Scientist, and ${ }^{6}$ Research Associate, USDA-ARS Northwest Watershed Research Center, Boise, ID 83712, USA; ${ }^{5}$ PhD Candidate, Department of Geosciences, Boise State University, Boise, ID 83725, USA; and ${ }^{7}$ Postdoctoral Research Fellow, Department of Biological and Agricultural Engineering, University of Idaho, Moscow, ID 83844, USA.
\end{abstract}

\begin{abstract}
Extensive woodland expansion in the Great Basin has generated concern regarding ecological impacts of tree encroachment on sagebrush rangelands and strategies for restoring sagebrush steppe. This study used rainfall $\left(0.5 \mathrm{~m}^{2}\right.$ and $13 \mathrm{~m}^{2}$ scales $)$ and concentrated flow simulations and measures of vegetation, ground cover, and soils to investigate hydrologic and erosion impacts of western juniper (Juniperus occidentalis Hook.) encroachment into sagebrush steppe and to evaluate short-term effects of burning and tree cutting on runoff and erosion responses. The overall effects of tree encroachment were a reduction in understory vegetation and formation of highly erodible, bare intercanopy between trees. Runoff and erosion from high-intensity rainfall (102 $\mathrm{mm} \cdot \mathrm{h}^{-1}, 13 \mathrm{~m}^{2}$ plots) were generally low from unburned areas underneath tree canopies $\left(13 \mathrm{~mm}\right.$ and $\left.48 \mathrm{~g} \cdot \mathrm{m}^{-2}\right)$ and were higher from the unburned intercanopy $\left(43 \mathrm{~mm}\right.$ and $\left.272 \mathrm{~g} \cdot \mathrm{m}^{-2}\right)$. Intercanopy erosion increased linearly with runoff and exponentially where bare ground exceeded $60 \%$. Erosion from simulated concentrated flow was 15 - to 25 -fold greater from the unburned intercanopy than unburned tree canopy areas. Severe burning amplified erosion from tree canopy plots by a factor of 20 but had a favorable effect on concentrated flow erosion from the intercanopy. Two years postfire, erosion remained 20 -fold greater on burned than unburned tree plots, but concentrated flow erosion from the intercanopy ( $76 \%$ of study area) was reduced by herbaceous recruitment. The results indicate burning may amplify runoff and erosion immediately postfire. However, we infer burning that sustains residual understory cover and stimulates vegetation productivity may provide long-term reduction of soil loss relative to woodland persistence. Simply placing cut-downed trees into the unburned intercanopy had minimal immediate impact on infiltration and soil loss. Results suggest cut-tree treatments should focus on establishing tree debris contact with the soil surface if treatments are expected to reduce short-term soil loss during the postcut understory recruitment period.
\end{abstract}

Key Words: infiltration, restoration, runoff, SageSTEP, tree removal, woodland encroachment

\section{INTRODUCTION}

Surface soil erosion is a primary threat to sustainability of Great Basin sagebrush steppe (Miller et al. 2011). An estimated one-third of presettlement sagebrush steppe has been degraded by anthropogenic disturbances and invasive plants that promote runoff and soil loss (McIver et al. 2010; Davies et al. 2011; Miller et al. 2011; Pierson et al. 2011). Disturbances and plant community transitions on rangelands commonly induce amplified runoff and erosion through degradation of a runoff-attenuating plant community structure and alteration of surface soils (Pierson et al. 1994; Wilcox et al. 2003; Ludwig et

This is Contribution Number 59 of the Sagebrush Steppe Treatment Evaluation Project (SageSTEP), funded by the US Joint Fire Science Program, Bureau of Land Management, and the National Interagency Fire Center.

Mention of a proprietary product does not constitute endorsement by USDA and does not imply its approval to the exclusion of the other products that may also be suitable.

USDA is an equal opportunity provider and employer.

Correspondence: Frederick B. Pierson, USDA-ARS Northwest Watershed Research Center, 800 Park Blvd, Suite 105, Boise, ID 83712, USA. Email: fred.pierson@ars. usda.gov

Manuscript received 10 August 2012; manuscript accepted 27 February 2013.

(c) 2013 The Society for Range Management al. 2005; Pierson et al. 2009, 2010). Extensive bare ground on degraded rangelands promotes runoff and soil erosion by rainsplash, sheetflow, and concentrated flow processes (Pierson et al. 2011). Substantial erosion of the biologically and hydrologically important surface-soil horizon on rangelands inhibits infiltration, reduces soil water storage, and negatively impacts plant productivity (Blackburn and Skau 1974; Schlesinger et al. 1990; Abrahams et al. 1995; Turnbull et al. 2010). For sagebrush steppe, this feedback may cause a site to shift from a healthy, resource-conserving state to a rapidly degrading one with respect to water and soil retention (Wilcox et al. 1996; Davenport et al. 1998; Wilcox et al. 2003; Pierson et al. 2010). Rapidly degrading sites may further transition to an eroded state in which only invasive species capable of tolerating the altered soil conditions can persist (Petersen et al. 2009). In the Great Basin, this process of desertification influences not only plant, soil, and water resources, but also key sagebrush steppe obligate wildlife species (Knick et al. 2003), forage for wild and domestic grazing animals, and local and regional economies (Pellant et al. 2004; Davies et al. 2011).

Woodland encroachment into Great Basin sagebrush steppe has been directly linked to plant community coarsening (Miller et al. 2000, 2005, 2008) and amplified runoff and soil loss (Pierson et al. 2007; Petersen and Stringham 2008; Petersen et al. 2009; Cline et al. 2010; Pierson et al. 2010). The influence of 
woodland encroachment on ecological processes is related to the encroachment phase (Miller et al. 2005). Woodland encroachment potentially progresses through three basic phases depending on site invasibility and disturbance: (1) Phase I-tree cover $(<1$ to $3 \mathrm{~m}$ height) expands, but shrubs and herbaceous species remain the dominant cover and control on ecological processes; (2) Phase II-tree cover increases to $10-49 \%$, shrub and herbaceous cover decline, and trees begin influencing key ecological processes; and (3) Phase III-tree cover stabilizes, is the dominant cover type ( $>75 \%$ shrub mortality), and exerts the primary control on ecological processes (Miller et al. 2000, 2005; Johnson and Miller 2006; Miller et al. 2008). Recent rainfall simulation studies by Pierson et al. $(2007,2010)$ reported accelerated erosion rates from areas between tree canopies (intercanopy) on late-Phase II-III woodland-encroached shrub steppe sites in the Great Basin. The studies attributed high soil loss from intercanopy areas to woodland encroachment-induced bare ground connectivity, accumulation of high-velocity concentrated overland flow, and efficient transport of rainsplash and flow detached sediment. Petersen et al. (2009) also found understory decline on woodland encroached sagebrush rangelands promoted runoff generation and suggested that long-term erosion from late-succession (e.g., Phase III) woodlands inhibits reversibility to the pre-encroachment ecologic structural-functional state (e.g., Briske et al. 2008).

The extensive expansion of pinyon (Pinus monophylla Torr. \& Frén, Pinus edulis Englem.) and juniper (J. oteosperma [Torr.] Little, J. occidentalis Hook.) into Great Basin sagebrush steppe and the potential ecological ramifications have evoked restoration concerns. Davies et al. (2011) and Miller et al. (2011) reported pinyon and juniper woodlands in the Intermountain West now occupy 19 million ha, $90 \%$ of which was sagebrush rangeland pre-European settlement. Miller et al. (2005) estimated western juniper (J. occidentalis Hook.) occupies 4 million ha in the Intermountain West, and several million additional ha of sagebrush habitat are at risk of displacement, expansion, or infill (Miller et al. 2011). Land owners, management agencies, and scientists across the western United States are actively seeking sagebrush steppe restoration guidelines and quantification of the effects of tree removal (McIver et al. 2010). In this study, we investigated the effects of western juniper encroachment on runoff and erosion and evaluated the short-term effects of burning and tree cutting on hydrologic and erosion responses. The primary objectives of the study were to (1) quantify vegetation, ground cover, and soil characteristics and hillslope runoff and erosion from rainsplash, sheetflow, and concentrated flow processes among areas underneath tree canopies (subcanopy) and in the intercanopy, (2) identify key soil and cover indicators of hydrologic and erosion vulnerability, (3) evaluate short-term hydrologic and erosion responses of intercanopy and subcanopy areas to wildfire, and (4) investigate immediate hydrologic and erosion effects of placing cut trees in the intercanopy.

\section{METHODS}

\section{Research Site}

Experiments were conducted on unburned and burned areas of a western juniper-dominated site as part of the Sagebrush
Steppe Treatment Evaluation Project (SageSTEP; McIver et al. 2010). SageSTEP was established to investigate the ecological impacts of invasive plants and woodland encroachment into Great Basin sagebrush steppe and the effects of various restoration methods, including prescribed fire and mechanical tree removal. The study site, Castlehead, is located at latitude $42^{\circ} 26^{\prime} 50^{\prime \prime}$ and $116^{\circ} 46^{\prime} 39^{\prime \prime}$ longitude on the Owyhee Plateau in southwestern Idaho, USA, approximately $200 \mathrm{~km}$ southwest of Boise. The site is managed by the Bureau of Land Management and was excluded from grazing $1 \mathrm{yr}$ prior to and throughout the study period. Detailed site topography, climate, soils, and vegetation characteristics are provided in Table 1. Annual precipitation at the site is dominated by winter season snowfall, with most of the remaining precipitation occurring as frontal rainfall events during the spring and autumn. Summers are hot and dry with occasional convective thunderstorm events. The primary vegetation cover at the site is western juniper. The understory cover consists of degraded sagebrush steppe vegetation. The study site was established in 2005 for the SageSTEP study, and field reconnaissance for experiments was conducted in 2006. In 2007, the 18890 ha Tongue Complex Wildfire severely burned portions of the study area. Live canopy and surface litter cover were completely consumed by the wildfire. Burned areas were left with a residual cover of ash and charred, standing dead trees and shrub skeletons. Unburned and burned experimental areas for this study were selected immediately after the fire and were located within 300 $\mathrm{m}$ of one another on the same elevation, aspect, prevailing slope angle, and mapped soil type. Field reconnaissance prior to the fire observed consistent vegetation and ground cover characteristics across the study area with exception of generally smaller tree size and greater tree density in areas subsequently burned.

\section{Study Design}

A suite of runoff and erosion experiments were performed at the Castlehead site 1 (Year 1-June 2008) and 2 (Year 2-June 2009) yr following the Tongue Complex Wildfire. Rainfall simulations were conducted on unburned and burned areas at the small-plot $(0.7 \mathrm{~m} \times 0.7 \mathrm{~m})$ scale in Years 1 and 2 and at the large-plot $(2 \mathrm{~m}$ wide $\times 6.5 \mathrm{~m}$ long) scale in Year 1 . Small plots were used to quantify runoff and erosion from rainsplash and sheetflow processes, while large plots (Figs. 1A and 1B) were used to quantify runoff and erosion from rainsplash, sheetflow, and concentrated-flow processes (Pierson et al. 2009, 2010). Concentrated flow experiments ( $2 \mathrm{~m}$ wide $\times 4.5 \mathrm{~m}$ long) were conducted within unburned and burned large plots immediately following rainfall simulations in Year 1 and as independent (without large plot simulations) experiments in Year 2. Concentrated flow experiments were used to measure erosion solely from concentrated flow or rill processes (Pierson et al. 2008a, 2009, 2010; Al-Hamdan et al. 2012a).

Small plots were placed on either juniper or shrub coppices (areas influenced by tree or shrub canopy) or in the interspaces between tree and shrub canopies to partition microsite contributions to runoff and erosion from the small-plot to the patch scale $\left(10-30 \mathrm{~m}^{2}\right)$. Small plot frames, made of sheet metal, were installed immediately before simulation in Year 1 and were left in place for sampling in Year 2. In Year 1, eight small 
Table 1. Topographic, climatic, soil, and cover (30 $\mathrm{m} \times 33 \mathrm{~m}$ plots in Year $1, n=3$ per treatment) characteristics of the Castlehead study site in southwestern Idaho, United States. Means within a row followed by a different lowercase letter are significantly different $(P<0.05)$.

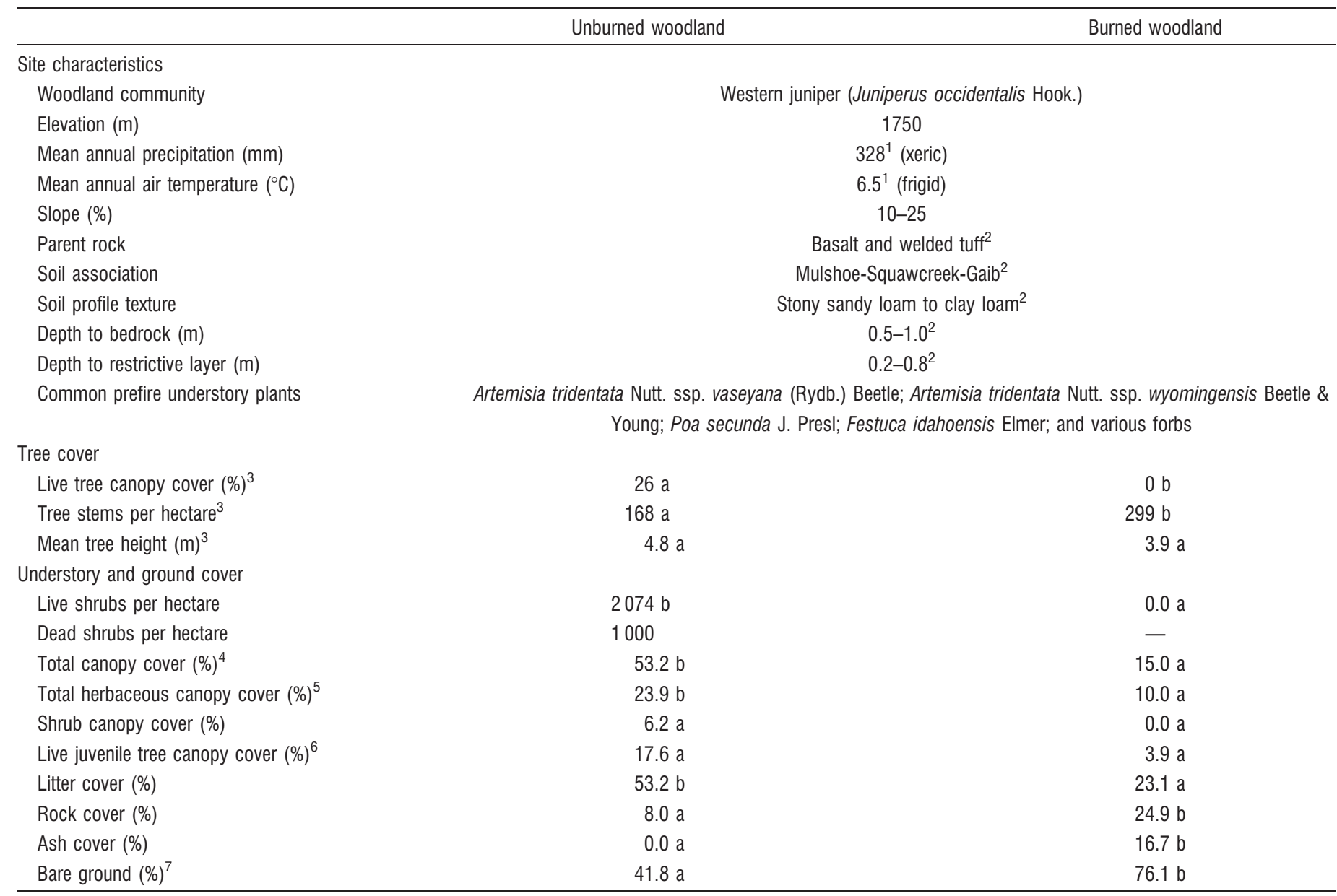

${ }^{1}$ Prism Group 2011.

${ }^{2}$ NRCS 2003.

${ }^{3}$ Unburned live and burned dead trees $\geq 1.0 \mathrm{~m}$ height.

${ }^{4}$ Excludes trees $>1.0 \mathrm{~m}$ height.

${ }^{5}$ Grass and forb canopy cover.

${ }^{6}$ Western juniper $<1.0 \mathrm{~m}$ height.

${ }^{7}$ Rock, ash, and bare soil.

plots were sampled on each unburned microsite, five small plots were sampled on burned juniper and shrub coppices, and 10 small plots were sampled on burned interspaces. Small plot sampling in Year 2 was consistent with Year 1 for burned plots but was reduced to three each for unburned juniper and shrub coppices and to four unburned interspaces. Plot installation procedures were as described by Pierson et al. (2010). Trees were cut by chainsaw and removed from juniper coppice plots immediately preceding experiments to minimize canopy interference with rainfall and plot sampling. Shrubs were retained on small plots, but were trimmed along plot boundaries to prevent stemflow from exiting or entering the respective plot.

Large rainfall and concentrated flow plots were installed on either shrub-interspace zones (varying amounts of shrub coppice and interspace area) or tree zones (juniper coppice with minor interspace component) to evaluate runoff and erosion contributions from the juniper coppice and shrubinterspace patch scales to the hillslope scale. The immediate hydrologic and erosional effects of tree cutting (cut-downed tree treatment) were examined by cutting (live) and placing a juniper tree on individual unburned shrub-interspace largerainfall (Year 1) and concentrated-flow (Years 1 and 2) plots. Cut trees were placed on plots with the long axis of the tree partially in contact with and parallel to the ground surface, perpendicular to the predominant hillslope contour (Fig. 1C). The average height, trunk diameter, and crown diameter for cut trees placed on plots were $2.8 \mathrm{~m}, 11.9 \mathrm{~cm}$, and $1.4 \mathrm{~m}$, respectively. Six large-plot rainfall simulations were performed for each microsite-treatment combination in Year 1, and six concentrated flow experiments were conducted per micrositetreatment combination in Years 1 and 2. Plot installation procedures were consistent with Pierson et al. (2010) with exception of Year 2 concentrated flow plots. Runoff collection troughs in Year 2 were installed in a "V" pattern at the base of each plot, as in Year 1, but without plot borders (Fig. 1B). As with small plots, standing juniper trees were removed from large rainfall and concentrated flow plots and shrubs were retained, but trimmed to prevent stemflow from exiting or entering plots. 

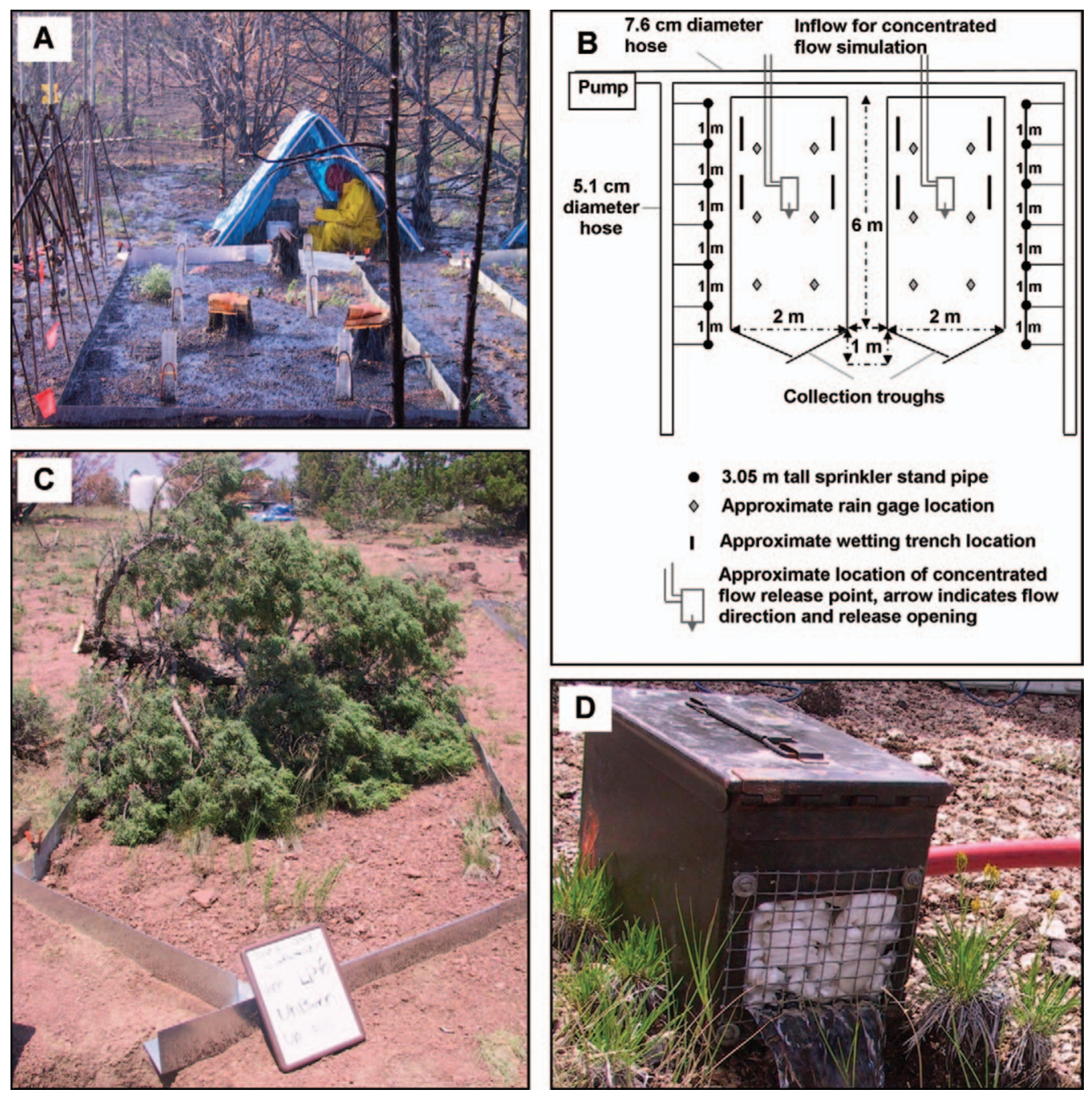

Figure 1. Illustration showing large-plot rainfall simulation on burned treatment (A), paired large-plot layout and design (B), single large plot (13 $\left.\mathrm{m}^{2}\right)$ in a shrub-interspace zone with cut-downed tree treatment (C), and concentrated flow release (D). Figure modified from Pierson et al. (2010).

\section{Vegetation and Soils Sampling}

Hillslope-scale tree cover, ground and canopy cover by cover type, and tree and shrub densities were measured on $30 \mathrm{~m} \times 33$ $\mathrm{m}$ randomly located site-characterization plots in burned $(n=3)$ and unburned $(n=3)$ areas in Year 1 . The height and maximum and minimum crown diameters were measured for each live tree. A crown radius for each live tree was calculated as the average of minimum and maximum crown radii and was used to calculate live tree crown cover with the assumption that crown cover is equivalent to area of a circle. Tree density on each plot was derived as the number of trees greater than $0.5 \mathrm{~m}$ height. Ground and canopy cover were measured on each site characterization plot using the line-point intercept method (Herrick et al. 2005) along five 30-m transects, spaced 5-8 m apart and perpendicular to hillslope contour. Plot ground and canopy cover were sampled at 60 points with $50-\mathrm{cm}$ spacing along each of the five transects for a total of 300 sample points per plot. The number of live and dead shrubs exceeding $5-\mathrm{cm}$ height were counted along three 2 -m wide by 30-m long belt transects, spaced $6 \mathrm{~m}$ apart within each site-characterization plot. Mean tree, shrub, and cover variables for unburned and burned areas were estimated as the average of measurements from the site-characterization plots in the respective treatment and were used to establish the phase of juniper encroachment at the site (Miller et al. 2005; Johnson and Miller 2006; Miller et al. 2008).

Ground cover, canopy cover, and surface roughness on each small plot were measured using seven point-frame transects spaced $10 \mathrm{~cm}$ apart and parallel to hillslope contour. Cover and roughness measures were recorded at 15 points $(5-\mathrm{cm}$ spacing) on each transect for a total of 105 sample points per plot. Percent cover for each cover type was derived from the frequency of respective cover hits divided by 105 . The relative ground-surface height at each sample point was calculated as the distance between the ground surface and the point-frame level line at the respective point. Ground surface roughness was estimated as the arithmetic average of the standard deviations of the ground surface heights for each of the seven transects sampled within each plot. The depth of litter on the ground surface was measured adjacent to each small plot at four evenly spaced points along each of the two small plot borders oriented perpendicular to the hillslope contour.

Ground and canopy cover on large rainfall simulation and concentrated flow plots were measured using line-point 
intercept procedures (Herrick et al. 2005). Cut trees placed on large-rainfall and concentrated-flow plots were excluded from ground and canopy cover measurements. Ground and canopy cover in Year 1 were recorded for 59 points with $10-\mathrm{cm}$ spacing, along each of five transects $6 \mathrm{~m}$ in length and $40 \mathrm{~cm}$ apart, oriented perpendicular to the hillslope contour (295 points $\left.\cdot \operatorname{plot}^{-1}\right)$. In Year 2, ground and canopy cover on concentrated flow plots were recorded at 24 points with 20$\mathrm{cm}$ spacing, along each of nine line-point transects $4.6 \mathrm{~m}$ in length spaced $20 \mathrm{~cm}$ apart $\left(216\right.$ points $\cdot$ plot $\left.^{-1}\right)$. The relative ground-surface height along line-point intercept transects was calculated as the distance between the ground surface and a survey transit level line above the respective sample point. The ground surface roughness for large-rainfall and concentrated flow plots was estimated as the arithmetic average of the standard deviations of the ground surface heights across the five line-point transects sampled within each plot.

Ground and canopy cover gaps on large rainfall and concentrated flow plots were estimated using the gap-intercept method along the ground and canopy cover line-point transects (Herrick et al. 2005). Distances between plant bases (basal gaps) and canopies (canopy gaps) are considered indicators of potential runoff and erosion (Herrick et al. 2005). Plant basal and canopy gaps exceeding $20 \mathrm{~cm}$ were recorded along each linepoint transect. Average basal and canopy gap sizes for each plot were determined as the mean of all respective gaps measured in excess of $20 \mathrm{~cm}$. Percentages of basal and canopy gaps representing gap classes $25-50 \mathrm{~cm}, 51-100 \mathrm{~cm}, 101-200 \mathrm{~cm}$, and $>200 \mathrm{~cm}$ were determined for each line-point transect and averaged across the five transects on each plot to determine gapclass plot means.

Surface soils for unburned and burned areas were characterized by sampling random surface locations stratified on tree coppice, shrub coppice, and interspace microsites. Surface soil samples were extracted from $0-2 \mathrm{~cm}$ depth from each of the microsites and were analyzed for soil texture using a Saturn DigiSizer Particle Size Analyzer (Micromeritics Instrument Corporation, Norcross, GA). Random soil samples were obtained for $0-5 \mathrm{~cm}$ depth and were analyzed gravimetrically for soil water content. Bulk density $(0-5 \mathrm{~cm}$ depth) was measured at multiple locations across the site using the compliant cavity method (Grossman and Pringle 1987). Surface soil aggregate stability for each small plot was determined using a modified sieve test described by Herrick et al. (2001, 2005). The test was performed on six surface soil aggregates (2-3 mm thick, 6-8 $\mathrm{mm}$ diameter) obtained immediately adjacent to each plot, and a stability class (Herrick et al. 2005) was assigned based on the mean test results for the six aggregates.

The strength of water repellency was measured over $0-5-\mathrm{cm}$ soil depth before rainfall simulation immediately adjacent to each small plot using the water drop penetration time (WDPT) procedure (DeBano 1981). The time required for water drop infiltration (up to $300 \mathrm{~s}$ ) was recorded for eight water drops (3$\mathrm{cm}$ spacing) applied at the mineral soil surface (ash and litter removed). Following this procedure $1 \mathrm{~cm}$ of soil was excavated immediately underneath the previously sampled area and the WDPT procedure was repeated for eight more drops. WDPT sample iterations continued to a depth of $5 \mathrm{~cm}$. Mean strength of water repellency at each $1-\mathrm{cm}$ depth for each plot was recorded as the average of the eight WDPT (s) samples. Soils were considered water repellent when WDPT exceeded $5 \mathrm{~s}$, slightly water repellent when WDPT ranged from 5 to $60 \mathrm{~s}$, and strongly water repellent when WDPT ranged from 60 to $300 \mathrm{~s}$ (Bisdom et al. 1993).

\section{Rainfall Simulations}

Rainfall was applied to small and large plots using methodology established by Pierson et al. (2010). Rainfall was applied at rates of $64 \mathrm{~mm} \cdot \mathrm{h}^{-1}$ (dry run) and $102 \mathrm{~mm} \cdot \mathrm{h}^{-1}$ (wet run) for $45 \mathrm{~min}$. The dry run was conducted with uniform dry antecedent soil moisture conditions, and the wet run was applied within 30 min following the dry run. The dry run intensity over 5-, 10-, and 15-min durations is equivalent to respective local storm return intervals of 4,8 , and $20 \mathrm{yr}$, and the wet run intensity over the same durations is equivalent to local storm return intervals of 14, 33, and $75 \mathrm{yr}$ (Hanson and Pierson 2001). Rainfall was applied to small plots with a portable oscillating-arm rainfall simulator using $80-100$ Veejet nozzles (Meyer and Harmon 1979; Pierson et al. 2008a, 2009, 2010). Paired large rainfall simulations were conducted with a Colorado State University-type rainfall simulator (Holland 1969; Pierson et al. 2007, 2009, 2010). The simulator consists of seven stationary sprinklers elevated $3.05 \mathrm{~m}$ above the ground surface along each outside plot border of paired large plots (Figs. 1A and 1B). Timed samples of plot runoff were collected at 1-min to 3-min intervals throughout each 45-min rainfall simulation and were analyzed for runoff volume and sediment concentration. The small and large plot rainfall simulators, rainfall characteristics and calibration procedures, and runoff sample processing are described in detail by Pierson et al. (2010).

A set of hydrologic response variables was derived for each small and large plot rainfall simulation. A mean runoff rate $\left(\mathrm{mm} \cdot \mathrm{h}^{-1}\right)$ was calculated for each runoff sample interval as the cumulative runoff divided by the interval time. The cumulative runoff $(\mathrm{mm})$ from each 45-min simulation was calculated as the integration of runoff rates over the total time of runoff. A runoff-to-rainfall ratio was derived by dividing cumulative runoff by total rainfall applied. Mean infiltration and erosion variables were calculated for plots that generated runoff. An average infiltration rate $\left(\mathrm{mm} \cdot \mathrm{h}^{-1}\right)$ for each sample interval was calculated as the difference between applied rainfall and measured runoff divided by duration of the sample interval. Cumulative sediment yield $\left(\mathrm{g} \cdot \mathrm{m}^{-2}\right)$ was determined as the integrated sum of sediment collected during runoff and was extrapolated to plot unit area by dividing cumulative sediment by total plot area. A sediment-to-runoff ratio $\left(\mathrm{g} \cdot \mathrm{m}^{-2} \cdot \mathrm{mm}^{-1}\right)$ was obtained by dividing cumulative sediment yield by cumulative runoff.

Soil profile wetting patterns were investigated over $0-20-\mathrm{cm}$ depths immediately following dry-run rainfall simulations on each small plot (Pierson et al. 2010). Wetting patterns were measured by excavating $50-\mathrm{cm}$ long trenches to a depth of 20 $\mathrm{cm}$. Trenches were excavated immediately adjacent to each plot so as to not affect wet run simulations. The percent wetted area of each exposed soil profile was measured using a $4 \mathrm{~cm}^{2}$ grid. Each grid area was determined to be dry or wet based on the dominant condition in the grid area and a percent wetted area 
was calculated for soil depths $0-6 \mathrm{~cm}, 0-10 \mathrm{~cm}$, and $0-20 \mathrm{~cm}$ (Pierson et al. 2008b, 2010).

The effects of woodland encroachment, burning, and tree cutting on cross-scale runoff and erosion were evaluated by comparisons of measured large rainfall-plot and area-weighted small rainfall-plot runoff and erosion (Pierson et al. 1994). Large plot point-intercept data were used to determine the proportional shrub coppice, interspace, and juniper coppice area on each large plot. For unburned tree zone plots, shrub canopy cover was used as an estimate of the shrub coppice proportional area, and the juniper coppice proportional area was determined as the difference in shrub canopy cover and litter ground cover. The percentage interspace area in unburned tree zones was estimated as the remaining proportional plot area after deducting, from $100 \%$, the estimated shrub and tree coppice coverage. For shrub-interspace plots, shrub coppice area was estimated as the respective plot-measured percent shrub canopy cover and the remaining plot area was considered interspace. Prefire proportional area of interspace and shrub and juniper coppices could not be determined for burned large plots. Therefore, mean microsite area estimates from unburned tree and shrub-interspace zones were used to estimate smallplot microsite proportional areas within burned tree and shrubinterspace zones, respectively. Total area and cover for each area-weighted large plot were $13 \mathrm{~m}^{2}$ and $100 \%$ cover. Areaweighted cumulative runoff and soil loss for each large plot were obtained by multiplying mean, cumulative small-plot runoff and erosion values, for each respective unburned or burned microsite, by the estimated representative microsite proportional areas and summing the results for the entire plot.

\section{Concentrated Flow Experiments}

Concentrated overland flow was applied to each large/rainfall concentrated plot using computer-controlled flow regulators (see Pierson et al. 2010). Release rates of 15,30 , and 45 $\mathrm{L} \cdot \mathrm{min}^{-1}$ were applied to each large rainfall/concentrated plot within 1-2 hr after rainfall simulation in Year 1 and on each independent concentrated flow plot in Year 2. Year 2 concentrated flow plots were unconfined with respect to width given plot walls were not present. Concentrated flow plots in Year 2 were prewet with a gently misting sprinkler to generate similar surface soil moisture conditions as on Year 1 plots that received rainfall simulations prior to concentrated flow experiments.

The individual flow release rates were applied to each plot for $12 \mathrm{~min}$ from a single location, $4 \mathrm{~m}$ upslope of the collection trough apex (Fig. 1B). Release rate progression was consecutive from $15 \mathrm{~L} \cdot \mathrm{min}^{-1}$ to $45 \mathrm{~L} \cdot \mathrm{min}^{-1}$. Concentrated flow was routed through a metal box filled with Styrofoam pellets and was released through a $10-\mathrm{cm}$ wide mesh-screened opening at the base of the box (Fig. 1D; Pierson et al. 2008a, 2009, 2010). Plot runoff samples were collected at 2-min intervals for each 12-min flow rate simulation and were processed for runoff and sediment as described by Pierson et al. (2010). Runoff and erosion variables for each flow release rate were calculated for an 8-min period beginning at runoff initiation. The 8-min runoff and sediment variables were consistent with those for 45-min rainfall simulations. In Year 2, the area eroded by the dominant flow path formed during the cumulative 15-45
$\mathrm{L} \cdot \mathrm{min}^{-1}$ releases was measured as the incised cross-sectional area located $3 \mathrm{~m}$ downslope from the flow release point.

\section{Statistical Analyses}

All statistical analyses were conducted using SAS software, version 9.1.3 (SAS Institute 2007). Site characterization plot data were analyzed in a one-way analysis of variance (ANOVA) with two treatments levels: unburned and burned. Small plot data were analyzed using a repeated measures split-plot mixed model with two whole-plot or treatment factors: unburned and burned. Microsite was the small-plot subplot factor and had three levels: juniper coppice, shrub coppice, and interspace. A compound symmetry covariance structure was used for small plot analyses given there were only two sample dates for each treatment (Littell et al. 2006). Large-plot rainfall simulation data (Year 1 only) and Year 2 cover data from concentrated flow plots were analyzed using a split-plot mixed model with two treatment levels, unburned and burned, and two microsite levels, tree zone and shrub-interspace zone. Analyses of all concentrated flow data were conducted separately by year due to the methodological differences between Years 1 and 2 . Concentrated flow runoff and erosion were analyzed with a repeated measures mixed-model using two treatment levels, unburned and burned, and two microsite levels, tree zone and shrub-interspace zone. Flow release rate was the repeated measure for concentrated-flow runoff and erosion analyses, with three levels: 15,30 , and $45 \mathrm{~L} \cdot \mathrm{min}^{-1}$. Carryover effects of concentrated flow releases were modeled with an autoregressive order 1 covariance structure (Littell et al. 2006). Plot location was designated a random effect and treatment and microsite were considered fixed effects in all respective analyses. Normality and homogeneity were tested prior to ANOVA using the Shapiro-Wilk test and Levene's test (SAS Institute 2007) and deviance from normality was addressed by data transformation. Back-transformed results are reported. Mean separation was determined using the LSMEANS procedure with Tukey's adjustment. Significant effects were evaluated at the $P<0.05$ level.

\section{RESULTS}

\section{Vegetation and Soils}

Vegetation and ground cover characteristics at Castlehead suggest woodland encroachment has coarsened the plant community structure at the site. More than $90 \%$ of the unburned intercanopy ( $74 \%$ of total area) was interspace with extensive bare ground (bare soil and rock; Table 2). Approximately $50-70 \%$ of understory canopy and basal gaps within shrub-interspace zones exceeded $100 \mathrm{~cm}$ (Table 2). Shrub cover in the unburned intercanopy was minor (Table 2), and the shrub layer exhibited substantial thinning $(\sim 50 \%$ were dead; Table 1). A preponderance of shrub skeletons and widespread bare ground were also observed during prefire field reconnaissance in the area subsequently burned. Intercanopy bare ground expanse at the site was indicative of a Phase III woodland, but mature tree density, residual shrub cover, and juvenile tree recruitment were more typical of late Phase II encroachment (Table 1). The Castlehead site was therefore 


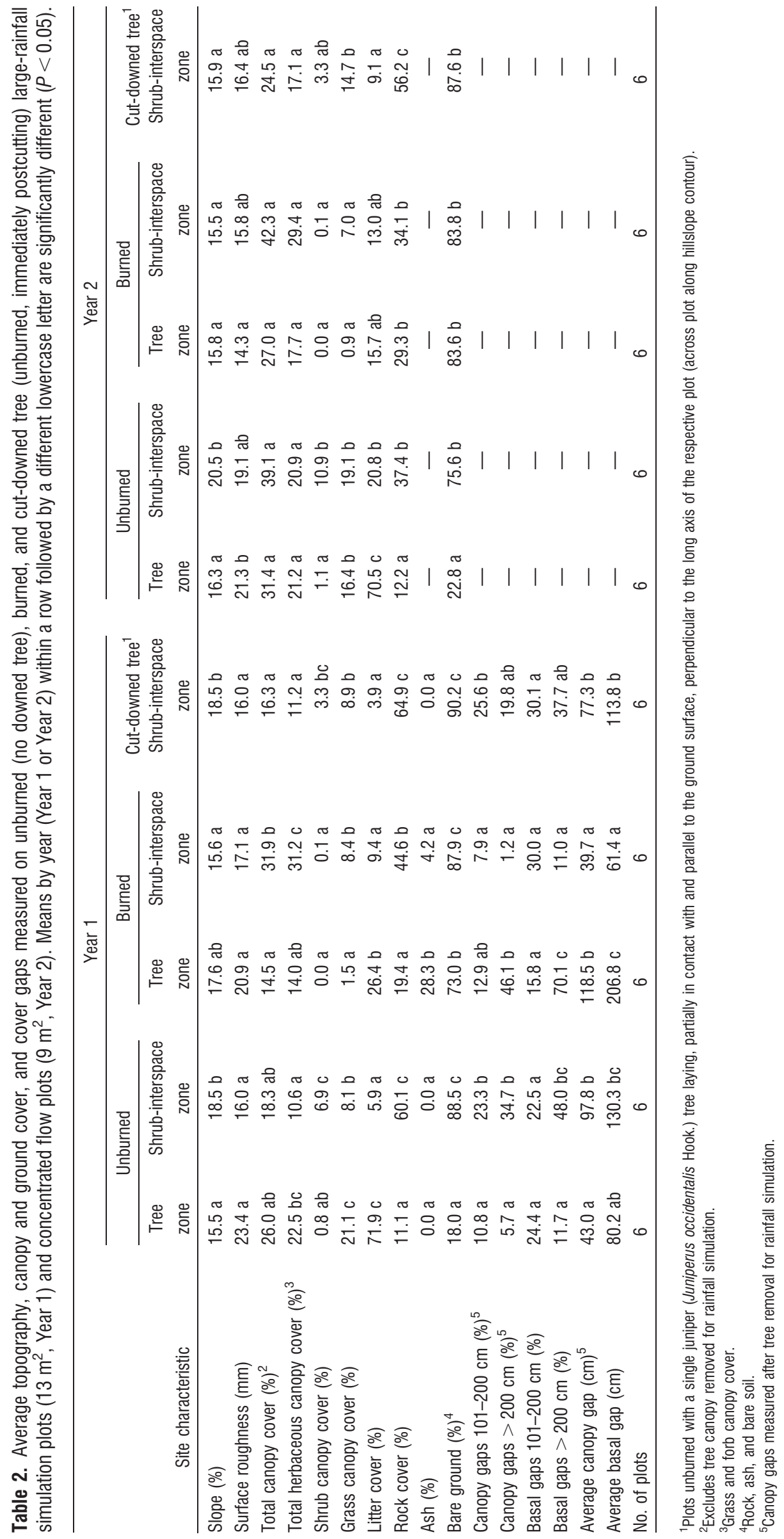


Table 3. Average topography, soil, and canopy and ground cover variables measured on unburned and burned small $\left(0.5 \mathrm{~m}^{2}\right)$ rainfall simulation plots 1 and 2 yr postfire. Means within a row followed by a different lower case letter are significantly different $(P<0.05)$.

\begin{tabular}{|c|c|c|c|c|c|c|c|c|c|c|c|c|}
\hline \multirow[b]{3}{*}{ Site characteristic } & \multicolumn{6}{|c|}{ Year 1} & \multicolumn{6}{|c|}{ Year 2} \\
\hline & \multicolumn{3}{|c|}{ Unburned } & \multicolumn{3}{|c|}{ Burned } & \multicolumn{3}{|c|}{ Unburned } & \multicolumn{3}{|c|}{ Burned } \\
\hline & $\begin{array}{l}\text { Juniper } \\
\text { coppice }\end{array}$ & $\begin{array}{c}\text { Shrub } \\
\text { coppice }\end{array}$ & Interspace & $\begin{array}{l}\text { Juniper } \\
\text { coppice }\end{array}$ & $\begin{array}{c}\text { Shrub } \\
\text { coppice }\end{array}$ & Interspace & $\begin{array}{l}\text { Juniper } \\
\text { coppice }\end{array}$ & $\begin{array}{l}\text { Shrub } \\
\text { coppice }\end{array}$ & Interspace & $\begin{array}{l}\text { Juniper } \\
\text { coppice }\end{array}$ & $\begin{array}{l}\text { Shrub } \\
\text { coppice }\end{array}$ & Interspace \\
\hline Slope (\%) & $20.8 \mathrm{bc}$ & $20.0 \mathrm{bc}$ & $13.9 \mathrm{a}$ & $17.1 \mathrm{abc}$ & $18.0 a b c$ & $16.2 \mathrm{ab}$ & $23.3 \mathrm{c}$ & $20.8 \mathrm{bc}$ & $16.2 \mathrm{ab}$ & $17.7 \mathrm{abc}$ & $17.5 a b c$ & $16.3 \mathrm{ab}$ \\
\hline Surface roughness $(\mathrm{mm})$ & 12 bc & $13 c$ & $9 a b$ & $8 \mathrm{a}$ & $9 a b$ & $8 \mathrm{a}$ & $10 a b c$ & $14 \mathrm{c}$ & $10 a b c$ & $9 a b$ & $11 a b c$ & $8 \mathrm{a}$ \\
\hline Aggregate stability class $(0-6)^{1}$ & $5 \mathrm{~b}$ & $3 \mathrm{a}$ & $2 \mathrm{a}$ & $5 \mathrm{~b}$ & $3 a$ & $2 \mathrm{a}$ & $6 \mathrm{~b}$ & $3 \mathrm{a}$ & $3 a$ & $2 \mathrm{a}$ & $2 \mathrm{a}$ & $3 \mathrm{a}$ \\
\hline Total canopy cover $(\%)^{2}$ & $17.0 \mathrm{~b}$ & $117.1 \mathrm{~cd}$ & $20.0 \mathrm{~b}$ & $4.6 \mathrm{a}$ & $20.5 b$ & $20.7 \mathrm{~b}$ & $6.0 \mathrm{a}$ & $143.8 \mathrm{~d}$ & $23.1 \mathrm{~b}$ & $25.3 \mathrm{~b}$ & $63.6 \mathrm{c}$ & $58.6 \mathrm{c}$ \\
\hline Total herbaceous canopy cover (\%) ${ }^{3}$ & $15.1 \mathrm{ab}$ & $47.3 \mathrm{c}$ & $18.4 \mathrm{~b}$ & $3.7 \mathrm{a}$ & $16.4 \mathrm{~b}$ & $18.6 \mathrm{~b}$ & $3.5 \mathrm{a}$ & $45.4 \mathrm{c}$ & $12.6 \mathrm{ab}$ & $17.5 \mathrm{~b}$ & $32.0 \mathrm{c}$ & $32.8 \mathrm{c}$ \\
\hline Shrub canopy cover (\%) & $0.1 \mathrm{a}$ & $66.0 \mathrm{~b}$ & $0.0 \mathrm{a}$ & $0.0 \mathrm{a}$ & $0.0 \mathrm{a}$ & $0.2 \mathrm{a}$ & $0.0 \mathrm{a}$ & $79.2 \mathrm{~b}$ & $0.0 \mathrm{a}$ & $0.0 \mathrm{a}$ & $2.9 \mathrm{a}$ & $0.0 \mathrm{a}$ \\
\hline Grass canopy cover (\%) & $11.7 \mathrm{~cd}$ & $44.8 \mathrm{e}$ & $15.0 \mathrm{~d}$ & $0.0 \mathrm{a}$ & $2.2 \mathrm{ab}$ & $6.5 \mathrm{bc}$ & $3.5 a b$ & $44.8 \mathrm{e}$ & $12.4 \mathrm{~cd}$ & $1.0 \mathrm{a}$ & $2.5 a b$ & $7.5 \mathrm{bc}$ \\
\hline Litter cover (\%) & $97.6 \mathrm{~d}$ & $46.5 \mathrm{c}$ & $4.4 \mathrm{a}$ & $12.3 a b$ & $4.6 \mathrm{a}$ & $4.7 \mathrm{a}$ & $95.2 \mathrm{~cd}$ & $61.3 \mathrm{~cd}$ & $4.8 \mathrm{a}$ & $10.3 a b$ & $15.4 \mathrm{~b}$ & $12.9 \mathrm{~b}$ \\
\hline Rock cover (\%) & $0.0 \mathrm{a}$ & $15.5 \mathrm{ab}$ & $42.3 \mathrm{c}$ & $35.1 \mathrm{c}$ & $34.7 \mathrm{c}$ & $43.3 \mathrm{c}$ & $0.6 \mathrm{a}$ & $12.1 \mathrm{ab}$ & $38.2 \mathrm{c}$ & $40.8 \mathrm{c}$ & $28.7 \mathrm{bc}$ & $39.1 \mathrm{c}$ \\
\hline Ash (\%) & - & - & - & $2.8 \mathrm{~b}$ & $1.6 \mathrm{ab}$ & $0.1 \mathrm{a}$ & - & - & - & $0.0 \mathrm{a}$ & $0.0 \mathrm{a}$ & $0.0 \mathrm{a}$ \\
\hline Bare ground $(\%)^{4}$ & $0.1 \mathrm{a}$ & $40.8 \mathrm{~b}$ & $87.9 \mathrm{c}$ & $87.6 \mathrm{C}$ & $93.7 \mathrm{c}$ & $92.7 \mathrm{c}$ & $2.5 \mathrm{a}$ & $29.2 \mathrm{~b}$ & $90.2 \mathrm{c}$ & $89.3 \mathrm{c}$ & $81.5 \mathrm{C}$ & $84.4 \mathrm{C}$ \\
\hline Litter depth (mm) & $43 \mathrm{~b}$ & $1 \mathrm{a}$ & $0 \mathrm{a}$ & $2 \mathrm{a}$ & $4 \mathrm{a}$ & $0 \mathrm{a}$ & $61 c$ & $1 \mathrm{a}$ & $0 \mathrm{a}$ & $0 \mathrm{a}$ & $0 \mathrm{a}$ & $0 \mathrm{a}$ \\
\hline No. of plots & 8 & 8 & 8 & 5 & 5 & 10 & 3 & 3 & 4 & 5 & 5 & 10 \\
\hline
\end{tabular}

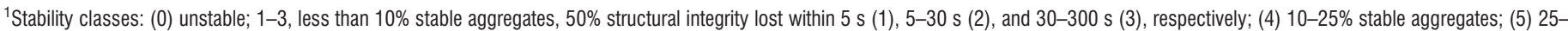
$75 \%$ stable aggregates; (6) 75-100\% stable aggregates (Herrick et al. 2001, 2005).

${ }^{2}$ Excludes tree canopy removed for rainfall simulation.

${ }^{3}$ Grass and forb canopy cover.

${ }^{4}$ Rock, ash, and bare soil.

likely in transition from Phase II to Phase III at the time of this study and had undergone substantial understory decline.

The Tongue Complex wildfire increased bare ground exposure at the site, but herbaceous recruitment postfire reduced the spatial connectivity of bare patches. The fire uniformly removed mature trees and shrubs and resulted in an average of $75-90 \%$ bare ground across all burned plots $1 \mathrm{yr}$ postfire (Tables 1-3). The majority of canopy and basal gaps measured on burned tree zone plots in Year 1 exceeded 100 and $200 \mathrm{~cm}$, respectively (Table 2). Canopy and basal gaps were generally smaller across burned than unburned shrub-interspace plots in Years 1 and 2. The differences in cover gaps between burned and unburned shrub-interspace plots 1 and 2 $\mathrm{yr}$ postfire were attributed to an even distribution of herbaceous cover, mostly perennial forbs, across burned shrub and interspace microsites (Table 3). In Year 2, only $2 \%$ of canopy and $20 \%$ of basal gaps exceeded $50 \mathrm{~cm}$ on burned shrub interspaces; approximately $30 \%$ of canopy gaps and $50 \%$ of basal gaps exceeded $50 \mathrm{~cm}$ on Year 2 unburned shrubinterspace plots. Herbaceous canopy cover averaged 20-30\% across unburned and burned small plots in Year 2. However, more than $75 \%$ of herbaceous canopy within unburned shrubinterspace zones in Year 2 was on shrub coppices whereas herbaceous canopy cover on burned shrub interspaces in Year 2 was well distributed on shrub and interspace microsites (Table 3 ). The canopy cover and gap data indicate burning recruited more uniform coverage of grasses and forbs across the intercanopy relative to unburned conditions. Extensive large $(>70 \mathrm{~cm})$ basal gaps with bare ground persisted in burned tree zones through Year 2, but these areas comprised less than 30\% of the study area.

Litter accumulation underneath juniper trees promoted aggregate stability and soil water repellency. Soil aggregates underneath 40-60-mm thick litter mats on unburned juniper coppices were $75-100 \%$ stable (Table 3 ). In contrast, soil aggregates under sparse litter layers on unburned and burned shrub coppices and interspaces were less than $10 \%$ stable (Table 3). The stability of soil aggregates on burned juniper coppices diminished to less than $10 \%$ by $2 \mathrm{yr}$ postfire. Soil water repellency was isolated to juniper coppices. Soils underneath unburned juniper litter mats were strongly water repellent (WDPT $>60 \mathrm{~s}$ ) for 0 - to 1 -cm soil depth and slightly water repellent $(5 \mathrm{~s}<$ WDPT $<60 \mathrm{~s})$ from 1 - to 5 -cm soil depth (Fig. 2). Soil water repellency on burned juniper coppices was generally similar across Years 1 and 2 and was slight at $0-3 \mathrm{~cm}$ and 5-cm soil depth and strong at 3- to 4-cm soil depth. The differences in depth of the strongest water repellent layer for burned versus unburned conditions suggest burning translocated preexisting or naturally occurring compounds which promote water repellency to deeper soil layers in a similar manner as commonly reported for forested ecosystems (DeBano et al. 1998; Doerr et al. 2009).

Surface soil physical properties, roughness, and soil moisture content varied minimally across unburned and burned areas. Mean bulk densities (0-5-cm depth) were $0.83,0.76$, and 1.04 $\mathrm{g} \cdot \mathrm{cm}^{-3}$ on juniper, shrub, and interspace microsites, respectively. Percent sand was generally lower and silt higher for interspaces than all coppice plots. Sand, silt, and clay $(0-2-\mathrm{cm}$ depth) averaged $64 \%, 33 \%$, and 3\% for all coppice plots and on interspaces were $46 \%, 49 \%$, and $5 \%$ for unburned and $55 \%, 39 \%$, and $6 \%$ for burned conditions. Surface roughness was highest for unburned shrub coppices at the small-plot scale, but was generally consistent across all plots at the largeplot scale (Tables 2 and 3). Antecedent soil moisture contents at $0-4-\mathrm{cm}$ depth were uniformly low $(<12 \%)$ across unburned and burned areas each year. 


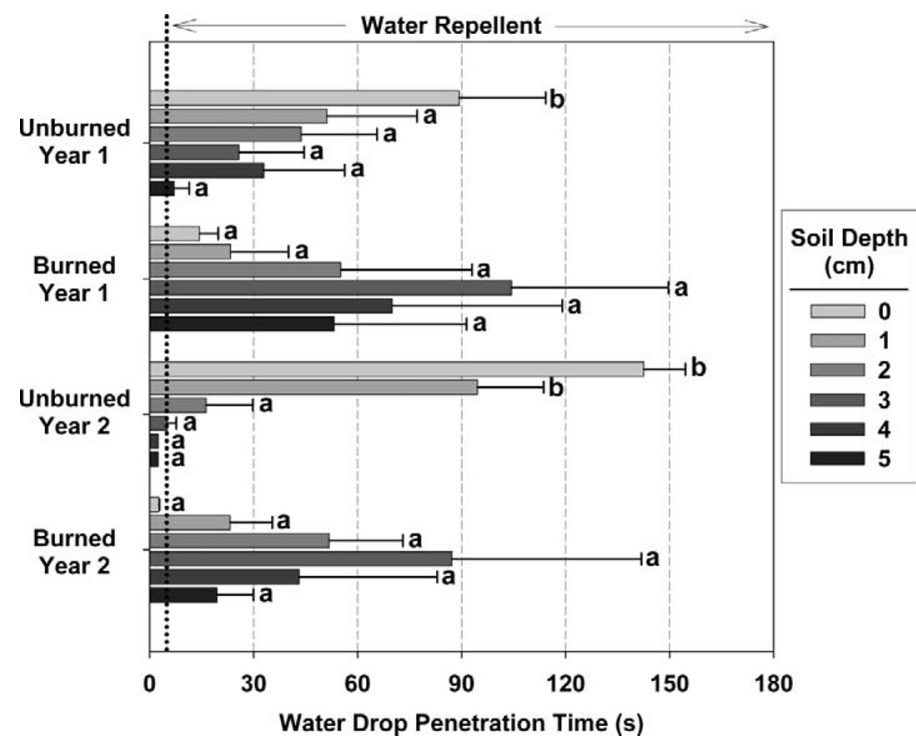

Figure 2. Water drop penetration times (WDPT, $300 \mathrm{~s}$ maximum) measured at $0-5-\mathrm{cm}$ soil depth underneath western juniper (Juniperus occidentalis Hook.) canopies on unburned and burned small rainfall simulation plots $(0.5$ $\mathrm{m}^{2}$ ) 1 and 2 yr postfire. Soils were considered water repellent when WDPT exceeded $5 \mathrm{~s}$ (indicated by vertical dotted line), slightly water repellent if WDPT ranged from 5 to $60 \mathrm{~s}$, and strongly water repellent if WDPT exceeded $60 \mathrm{~s}$ (Bisdom et al. 1993). Error bars depict standard error. Means within a soil depth across treatments and years followed by a different lower case letter are significantly different $(P<0.05)$.

Table 4. Average rainfall, runoff, infiltration, sediment, and wetting depth response variables for small-plot $\left(0.5 \mathrm{~m}^{2}\right)$ rainfall simulations on unburned and burned areas 1 and 2 yr postfire. Means within a row followed by a different lowercase letter are significantly different $(P<0.05)$.

\section{Small-Plot Rainfall Simulations}

Small-plot runoff generation was strongly influenced by microsite soil and cover characteristics. Runoff from dry-run simulations on unburned plots was 2- to 5-fold greater from interspaces than coppices (Table 4). Thick litter mats on tree coppices, dense shrub canopy cover on shrub coppices, and lower bulk densities across all coppices mitigated water repellency and promoted storage and infiltration of rainfall (Table 4). Dry-run sediment-to-runoff ratios were generally low $\left(<0.80 \mathrm{~g} \cdot \mathrm{m}^{-2} \cdot \mathrm{mm}^{-1}\right)$ across all unburned plots.

Fire effects on Year 1 dry-run runoff and erosion were much greater for juniper coppices than shrub coppices and interspaces. Mean infiltration rates were $25-40 \%$ lower on burned juniper plots with exposed ( $\sim 90 \%$ bare ground), strongly water repellent soils than on unburned juniper coppices and equally bare, burned interspace plots (Table 4). Only $64 \%$ of the soil profile from $0-10-\mathrm{cm}$ depth was wet following dry runs on burned juniper coppices (Table 4), whereas more than $80 \%$ was wet on all other unburned and burned Year 1 plots. Dryrun infiltration rates were slightly greater on burned interspaces than unburned interspaces but were unaffected by burning on shrub coppices (Table 4). Dry-run erosion was 17-fold greater from exposed surface soils on burned juniper coppices than from the litter-covered unburned juniper plots (Table 4). The dry-run sediment-to-runoff ratio was greater for burned than unburned interspaces, but cumulative erosion across both treatments was not different due to low runoff rates from the burned interspace plots (Table 4). Two years postfire, dry-run

\begin{tabular}{|c|c|c|c|c|c|c|c|c|c|c|c|c|}
\hline \multirow[b]{3}{*}{ Rainfall simulation variable } & \multicolumn{6}{|c|}{ Year 1} & \multicolumn{6}{|c|}{ Year 2} \\
\hline & \multicolumn{3}{|c|}{ Unburned } & \multicolumn{3}{|c|}{ Burned } & \multicolumn{3}{|c|}{ Unburned } & \multicolumn{3}{|c|}{ Burned } \\
\hline & $\begin{array}{l}\text { Juniper } \\
\text { coppice }\end{array}$ & $\begin{array}{l}\text { Shrub } \\
\text { coppice }\end{array}$ & Interspace & $\begin{array}{l}\text { Juniper } \\
\text { coppice }\end{array}$ & $\begin{array}{c}\text { Shrub } \\
\text { coppice }\end{array}$ & Interspace & $\begin{array}{l}\text { Juniper } \\
\text { coppice }\end{array}$ & $\begin{array}{c}\text { Shrub } \\
\text { coppice }\end{array}$ & Interspace & $\begin{array}{l}\text { Juniper } \\
\text { coppice }\end{array}$ & $\begin{array}{c}\text { Shrub } \\
\text { coppice }\end{array}$ & Interspace \\
\hline \multicolumn{13}{|l|}{ Dry run simulation $\left(64 \mathrm{~mm} \cdot \mathrm{h}^{-1}, 45 \mathrm{~min}\right)$} \\
\hline Applied rain (mm) ${ }^{1}$ & 47 & 47 & 47 & 47 & 47 & 47 & 47 & 47 & 47 & 47 & 47 & 48 \\
\hline Cumulative runoff (mm) & $8 a b$ & $4 \mathrm{a}$ & $20 \mathrm{~cd}$ & $19 \mathrm{~cd}$ & $5 a b$ & $12 \mathrm{bc}$ & $9 a b$ & $6 a b$ & $27 \mathrm{~d}$ & $22 \mathrm{~d}$ & $5 a b$ & $12 \mathrm{bc}$ \\
\hline Runoff-to-rainfall $\left(\mathrm{mm} \cdot \mathrm{mm}^{-1}\right) \times 100 \%$ & $17 \mathrm{ab}$ & $9 \mathrm{a}$ & $42 \mathrm{~cd}$ & $40 \mathrm{~cd}$ & $10 \mathrm{ab}$ & $26 \mathrm{bc}$ & $19 a b$ & $12 a b$ & $57 \mathrm{~d}$ & $47 d$ & $10 a b$ & $25 \mathrm{bc}$ \\
\hline Mean infiltration rate $\left(\mathrm{mm} \cdot \mathrm{h}^{-1}\right)^{2}$ & $50 \mathrm{bc}$ & - & 33 a & $31 \mathrm{a}$ & - & $42 \mathrm{~b}$ & $51 \mathrm{bc}$ & - & $27 \mathrm{a}$ & $33 \mathrm{a}$ & $55 \mathrm{c}$ & $46 \mathrm{bc}$ \\
\hline Cumulative sediment $\left(\mathrm{g} \cdot \mathrm{m}^{-2}\right)^{2}$ & $5 \mathrm{a}$ & - & $16 a b$ & $86 \mathrm{~d}$ & - & $43 \mathrm{bc}$ & $3 a$ & - & $19 a b$ & $62 \mathrm{~cd}$ & $14 \mathrm{a}$ & $14 \mathrm{a}$ \\
\hline Sediment/runoff $\left(\mathrm{g} \cdot \mathrm{m}^{-2} \cdot \mathrm{mm}^{-1}\right)^{2}$ & $0.79 \mathrm{a}$ & - & $0.71 \mathrm{a}$ & $3.31 \mathrm{~b}$ & - & $2.70 \mathrm{~b}$ & $0.65 \mathrm{a}$ & - & $0.70 \mathrm{a}$ & $2.45 b$ & $1.66 a b$ & $1.00 \mathrm{a}$ \\
\hline Percent wet at 0-6 cm depth & $77 \mathrm{~b}$ & $93 \mathrm{c}$ & $98 \mathrm{c}$ & $52 \mathrm{a}$ & $97 \mathrm{c}$ & $100 \mathrm{c}$ & $93 \mathrm{c}$ & $95 \mathrm{c}$ & $100 \mathrm{c}$ & 89 bc & $99 \mathrm{c}$ & $99 \mathrm{c}$ \\
\hline Percent wet at $0-10 \mathrm{~cm}$ depth & $80 \mathrm{~b}$ & $87 \mathrm{bc}$ & $96 \mathrm{c}$ & $64 \mathrm{a}$ & $87 \mathrm{bc}$ & $98 \mathrm{c}$ & $95 \mathrm{c}$ & $91 \mathrm{c}$ & $91 \mathrm{c}$ & $82 \mathrm{bc}$ & $94 \mathrm{c}$ & $98 \mathrm{c}$ \\
\hline Percent wet at $0-20 \mathrm{~cm}$ depth & $79 \mathrm{a}$ & $73 \mathrm{a}$ & $77 \mathrm{a}$ & $72 \mathrm{a}$ & $67 \mathrm{a}$ & $81 \mathrm{a}$ & $90 \mathrm{a}$ & $80 \mathrm{a}$ & $65 a$ & $74 \mathrm{a}$ & $74 \mathrm{a}$ & $85 \mathrm{a}$ \\
\hline Percent of plots with runoff ${ }^{1}$ & 88 & 25 & 88 & 80 & 40 & 80 & 100 & 67 & 100 & 100 & 80 & 90 \\
\hline \multicolumn{13}{|l|}{ Wet-run simulation $\left(102 \mathrm{~mm} \cdot \mathrm{h}^{-1}, 45 \mathrm{~min}\right)$} \\
\hline Applied rain $(\mathrm{mm})^{1}$ & 74 & 75 & 75 & 75 & 75 & 75 & 75 & 76 & 76 & 77 & 76 & 76 \\
\hline Cumulative runoff (mm) & $17 \mathrm{a}$ & $15 \mathrm{a}$ & $47 \mathrm{c}$ & $44 \mathrm{c}$ & $17 \mathrm{a}$ & $38 \mathrm{bc}$ & $17 \mathrm{a}$ & $20 \mathrm{a}$ & $57 \mathrm{c}$ & $52 \mathrm{c}$ & $23 a b$ & $43 \mathrm{c}$ \\
\hline Runoff-to-rainfall $\left(\mathrm{mm} \cdot \mathrm{mm}^{-1}\right) \times 100 \%$ & $23 a$ & $20 \mathrm{a}$ & $63 c$ & $58 \mathrm{c}$ & $23 \mathrm{a}$ & $51 \mathrm{bc}$ & $23 a$ & $26 \mathrm{a}$ & $74 \mathrm{c}$ & $68 c$ & $30 a b$ & $56 \mathrm{c}$ \\
\hline Mean infiltration rate $\left(\mathrm{mm} \cdot \mathrm{h}^{-1}\right)^{2}$ & $77 \mathrm{c}$ & $69 \mathrm{bc}$ & $38 \mathrm{a}$ & $43 \mathrm{a}$ & $72 \mathrm{bc}$ & $50 \mathrm{ab}$ & $77 \mathrm{c}$ & $75 \mathrm{bc}$ & $27 \mathrm{a}$ & $34 \mathrm{a}$ & $72 \mathrm{bc}$ & $45 \mathrm{a}$ \\
\hline Cumulative sediment $\left(\mathrm{g} \cdot \mathrm{m}^{-2}\right)^{2}$ & $6 \mathrm{a}$ & $6 \mathrm{a}$ & $36 \mathrm{a}$ & $206 \mathrm{~b}$ & $143 \mathrm{~b}$ & $135 \mathrm{~b}$ & $10 \mathrm{a}$ & $16 \mathrm{a}$ & $39 \mathrm{a}$ & $185 \mathrm{~b}$ & $64 \mathrm{a}$ & $72 \mathrm{a}$ \\
\hline Sediment/runoff $\left(\mathrm{g} \cdot \mathrm{m}^{-2} \cdot \mathrm{mm}^{-1}\right)^{2}$ & $0.36 \mathrm{a}$ & $0.27 \mathrm{a}$ & $0.71 \mathrm{a}$ & $3.97 \mathrm{c}$ & $4.61 \mathrm{c}$ & $2.97 \mathrm{bc}$ & $0.42 \mathrm{a}$ & $0.68 \mathrm{a}$ & $0.69 \mathrm{a}$ & $3.23 \mathrm{bc}$ & $1.77 \mathrm{ab}$ & $1.46 \mathrm{a}$ \\
\hline Percent of plots with runoff ${ }^{1}$ & 100 & 63 & 100 & 100 & 80 & 100 & 100 & 100 & 100 & 100 & 100 & 100 \\
\hline No. of plots & 7 & 8 & 8 & 5 & 5 & 10 & 3 & 3 & 3 & 5 & 5 & 10 \\
\hline
\end{tabular}

${ }^{1}$ Not included in statistical analysis.

${ }^{2}$ Means based solely on plots that generated runoff. 

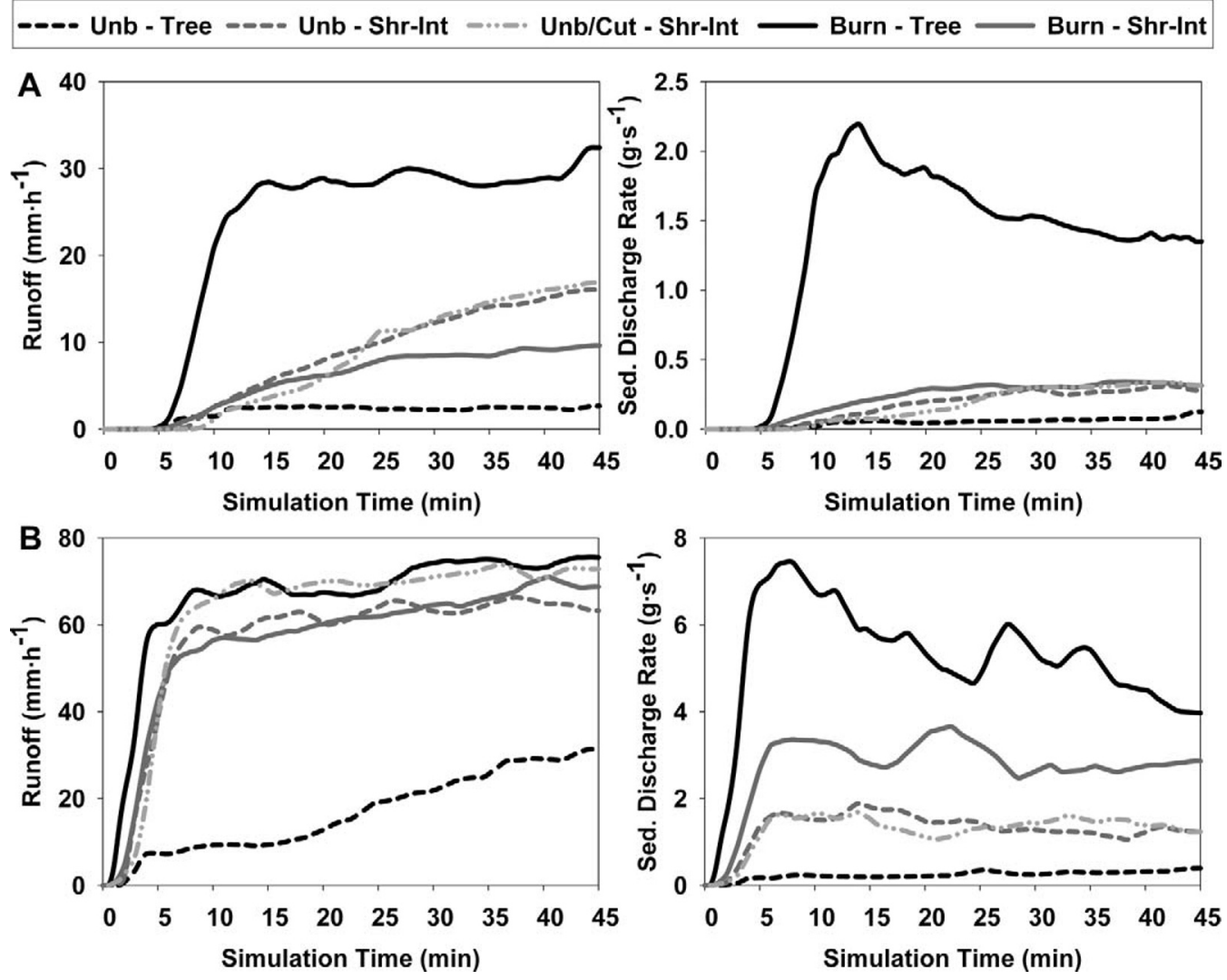

Figure 3. Runoff hydrographs and sedigraphs for large-plot $\left(13 \mathrm{~m}^{2}\right)$ dry run $\left(\mathbf{A} ; 64 \mathrm{~mm} \cdot \mathrm{h}^{-1}, 45 \mathrm{~min}\right)$ and wet run $\left(\mathbf{B} ; 102 \mathrm{~mm} \cdot \mathrm{h}^{-1}, 45 \mathrm{~min}\right)$ rainfall simulations on unburned (Unb, no downed tree), burned (Burn, $1 \mathrm{yr}$ postfire), and cut-downed tree (Unb/Cut, immediately postcut) treatments in tree (Tree, Juniperus occidentalis Hook.) and shrub-interspace (Shr-Int) zones.

runoff and erosion rates from burned juniper plots remained greater than measured on unburned juniper coppices, and infiltration remained higher on burned than unburned interspaces (Table 4). Dry-run cumulative erosion from burned shrub coppices and interspaces in Year 2 were similar to that measured on unburned plots.

Wet-run runoff and erosion trends were similar to those of the dry run, but the magnitude of differences in unburned and burned erosion rates was greater. Bare ground and high bulk density in interspaces promoted rapid runoff generation. Wetrun runoff for unburned conditions was threefold higher from interspaces than from juniper and shrub coppices, but sediment-to-runoff ratios were similar across all unburned plots (Table 4). Interspace runoff and infiltration were similar between fire treatments, but Year 1 erosion was fourfold greater for burned than unburned interspaces. Fire removal of litter on juniper plots amplified soil loss. Wet-run runoff and erosion in Year 1 from burned juniper coppices were twice that of the Year 1 dry-run and were more than 3- and 30-fold greater than from unburned juniper plots, respectively (Table 4). Runoff and infiltration in Year 1 were not different for burned and unburned shrub coppices, but erosion was more than 20-fold greater for burned conditions. Two years postfire, runoff and erosion were similar across treatments for shrub coppice and interspace plots, but remained amplified in the burn on juniper coppices relative to unburned conditions as observed for the dry run (Table 4).

\section{Large-Plot Rainfall Simulations}

The effects of woodland encroachment on runoff generation and erosion at the large-plot scale were heighten by the highintensity wet-run simulation and were unaffected by placement of cut trees across plots. Dry-run simulations generated low runoff and erosion rates from unburned large plots. Runoff and erosion from shrub-interspace zones were amplified by the higher intensity wet-run rainfall (Fig. 3), and erosion from the wet-run simulations was linearly correlated with runoff (Fig. 4). The wet-run intensity overwhelmed sources of surface water detention on unburned shrub-interspace plots, and high runoff rates (Fig. 3B) facilitated formation of erosive concentrated flow. Sediment discharge rates from unburned shrub-interspace zones were sevenfold higher for the wet- versus dry-run intensity (Fig. 3). In contrast, a fivefold increase in runoff for the wet versus dry runs on unburned tree zones did not result in amplified sediment discharge (Fig. 3). Water repellent soils enhanced wet-run runoff generation in tree zones, but litter cover protected the ground surface from detachment by rainfall and runoff. The effects of bare ground on shrub-interspace erosion are evident in the relationship between measured wetrun sediment yield and bare soil and rock cover on unburned large plots (Fig. 5). Simply placing cut trees across unburned shrub-interspace zones had no effect on runoff and erosion rates from dry and wet runs (Fig. 3), and the trend between cumulative runoff and erosion from downed tree plots was consistent with unburned shrub-interspace zones (Fig. 4). 


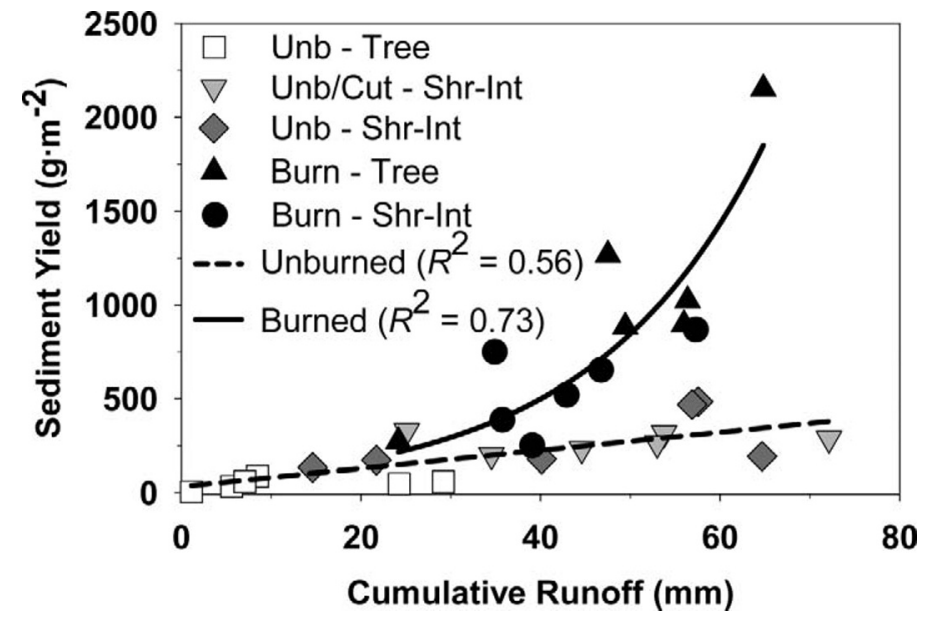

Figure 4. Cumulative sediment yield versus runoff from wet-run (102 $\mathrm{mm} \cdot \mathrm{h}^{-1}, 45 \mathrm{~min}$ ) rainfall simulations on unburned (Unb, no downed tree), cut-downed tree (Unb/Cut, immediately postcut), and burned (Burn, $1 \mathrm{yr}$ postfire) treatments in tree (Tree, Juniperus occidentalis Hook.) and shrubinterspace (Shr-Int) zones.

Fire removal of the litter layer on tree coppices exacerbated the effects of soil water repellency on runoff and erosion, but burning had no effect on runoff and erosion from degraded shrub-interspace zones. Runoff and sediment discharge rates were 4-8-fold and more than 20-fold higher, respectively, for burned than unburned tree coppice plots for dry- and wet-run simulations (Fig. 3). Reduced interception and storage by litter in tree zones postfire increased water availability for runoff from water repellent soils. Amplified runoff postfire in tree zones facilitated formation of concentrated flow paths with high sediment detachment and transport rates (Fig. 3). Runoff rates were consistent across burned tree and burned/unburned shrub-interspace zones, but higher sediment discharge rates for burned tree zones resulted in an exponential deviation in soil loss with respect to the runoff-erosion relationship for unburned plots (Fig. 4). The wet run produced $48 \mathrm{~g} \cdot \mathrm{m}^{-2}$ and $1083 \mathrm{~g} \cdot \mathrm{m}^{-2}$ cumulative erosion from unburned and burned tree zones respectively. The amount of sediment per unit of runoff from the wet-run was greater for burned (13.34 $\left.\mathrm{g} \cdot \mathrm{m}^{-2} \cdot \mathrm{mm}^{-1}\right)$ than unburned $\left(6.88 \mathrm{~g} \cdot \mathrm{m}^{-2} \cdot \mathrm{mm}^{-1}\right)$ shrub interspaces, but the greater erodibility did not generate differences in cumulative wet-run soil loss for burned (572 $\left.\mathrm{g} \cdot \mathrm{m}^{-2}\right)$ versus unburned $\left(272 \mathrm{~g} \cdot \mathrm{m}^{-2}\right)$ plots. The lack of significant fire effects on wet-run erosion from shrub-interspace zones is attributed to encroachment-induced degraded understory cover and high runoff and erosion rates within the unburned intercanopy.

\section{Runoff and Erosion Across Spatial Scales}

Erosion increased with increasing plot scale for unburned shrub-interspaces zones and burned areas 1 yr postfire even though runoff remained constant across plot scales. For Year 1, area-weighting small-plot wet-run runoff rates by microsite to the large-plot scale resulted in similar runoff estimates as measured in shrub-interspace and tree zone plots (Fig. 6A). In contrast, the same approach with small-plot erosion rates predicted 4- to 8 -fold less sediment yield than measured at the

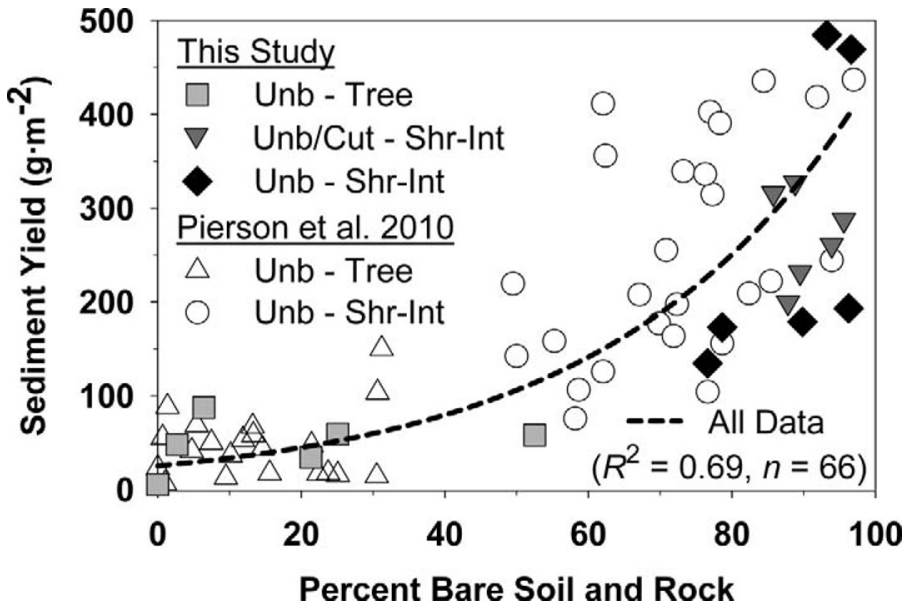

Figure 5. Cumulative sediment yield versus bare soil and rock cover from wet-run rainfall simulations (102 $\mathrm{mm} \cdot \mathrm{h}^{-1}, 45 \mathrm{~min}$ ) on unburned (Unb, no downed tree) and cut-downed tree (Unb/Cut, immediately postcut) treatments in tree (Tree, Juniperus occidentalis Hook.) and shrubinterspace (Shr-Int) zones at the Castlehead site (this study). Experiments by Pierson et al. (2010) are replicates of this study (13 $\mathrm{m}^{2}$ plots, 102 $\mathrm{mm} \cdot \mathrm{h}^{-1}, 45 \mathrm{~min}$ simulations) on unburned woodlands in the Great Basin, United States, and were conducted in a Utah juniper-singleleaf pinyon (Pinus monophylla Torr. and Frém-J. osteosperma [Torr.] Little) woodland and a Utah juniper woodland.

large-plot scale (Fig. 6B). The amplified cross-scale erosion without increased runoff clearly indicates concentrated flow was the dominate erosion process during wet-run simulations on shrub-interspace and burned tree zone plots 1 yr postfire. We observed concentrated flow underneath wet-run rainfall on most unburned shrub-interspace and burned large plots. Amplified cross-scale erosion and formation of concentrated flow on unburned shrub-interspace plots suggest woodland encroachment at the site is promoting soil loss over the plot scales investigated, $\sim 30 \mathrm{~m}^{2}$ area for paired large plots. The large differences in erosion across plot scales further indicate the surface soil at Castlehead has high erosion potential.

\section{Concentrated Flow Simulations}

Differences in ground cover across unburned and burned conditions 1 yr postfire influenced runoff and erosion from simulated overland flow, but placing cut trees in the intercanopy had no effect on shrub-interspace zone responses to concentrated flow releases. Degraded, shrub-interspace zones generated threefold more runoff and 15 -fold more erosion than unburned tree zones from the combined $15-45 \mathrm{~L} \cdot \mathrm{min}^{-1}$ concentrated flow releases (Table 5). The extensive bare surface in the unburned intercanopy inhibited infiltration of released overland flow, and the easily erodible surface provided ample sediment supply. Burning of litter in tree zones amplified cumulative runoff and erosion from $15-45 \mathrm{~L} \cdot \mathrm{min}^{-1}$ releases 2and 10 -fold in Year 1 and resulted in similar concentrated flow runoff across burned tree zones and all shrub-interspace plots (Table 5). Burning of shrub-interspace zones resulted in sixfold less cumulative erosion from the combined flow releases relative to unburned conditions due to differences in response to the $45 \mathrm{~L} \cdot \mathrm{min}^{-1}$ flow rate (Table 5). Smaller basal gaps (Table 2) and more evenly distributed grass and forb cover in 

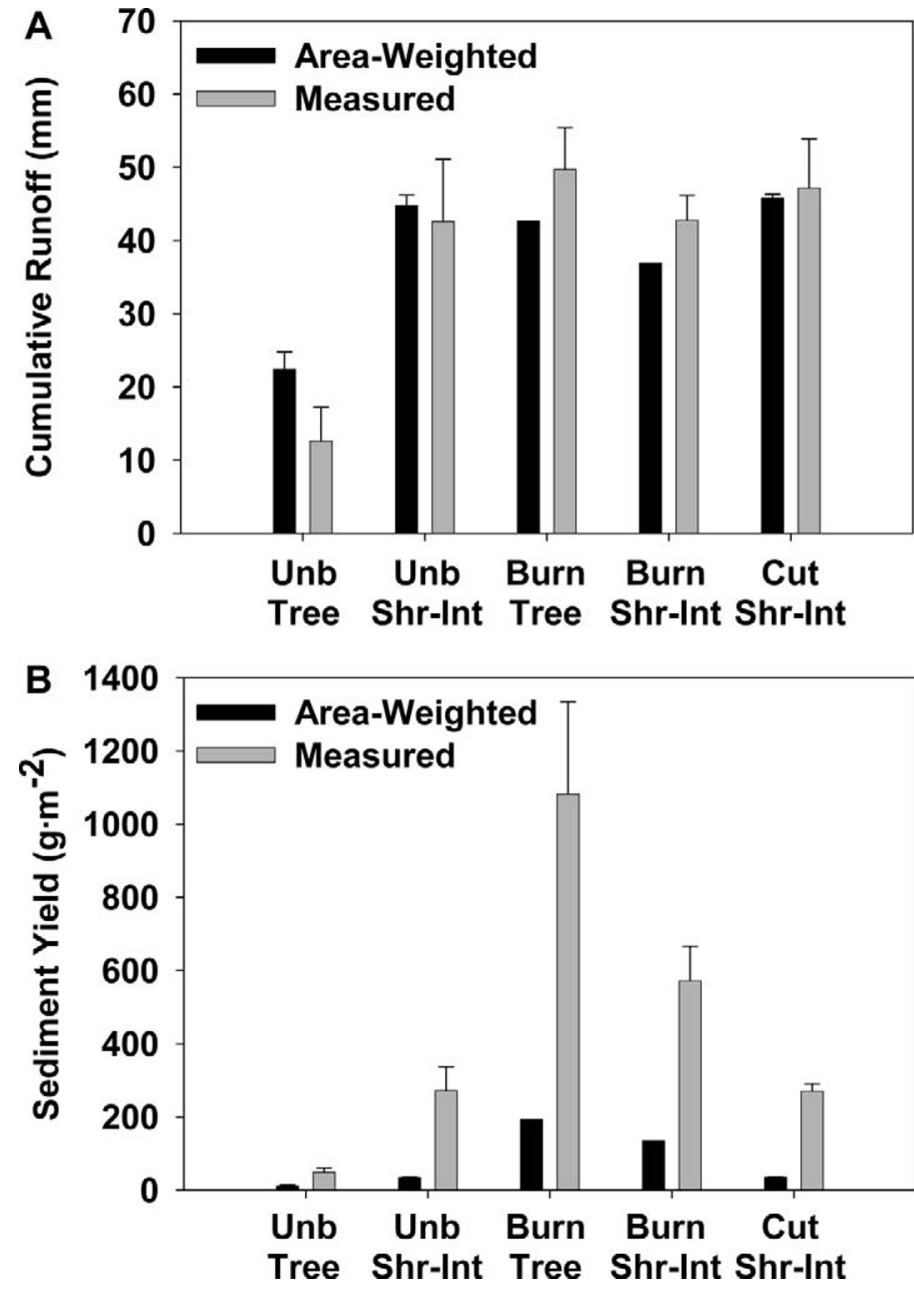

Figure 6. Large plot $\left(13 \mathrm{~m}^{2}\right)$ microsite area-weighted and measured cumulative runoff $(\mathbf{A})$ and sediment yield $(\mathbf{B})$ for wet-run rainfall simulations (102 $\mathrm{mm} \cdot \mathrm{h}^{-1}, 45 \mathrm{~min}$ ) on unburned (Unb, no downed tree), burned (Burn, $1 \mathrm{yr}$ postfire), and cut-downed tree (Unb/Cut, immediately postcut) treatments in tree (Tree, Juniperus occidentalis Hook.) and shrubinterspace (Shr-Int) zones. Individual large-plot, microsite area-weighted values were determined by area-weighting small plot $\left(0.5 \mathrm{~m}^{2}\right)$ wet-run runoff and sediment yield from unburned and burned tree coppice, shrub coppice, and interspace microsites based on respective large-plot cover representation. Error bars represent standard error.

Year 1 on burned versus unburned shrub interspaces likely attenuated the erosive energy of overland flow during the 45 $\mathrm{L} \cdot \mathrm{min}^{-1}$ release below that necessary to detach remaining soil particles. Mean cumulative soil loss measured in Year 1 from cumulative flow releases on unburned shrub-interspace plots with cut trees was not different than from unburned shrub interspaces without cut trees due to high variability in measured erosion. Concentrated flow on cut-tree treatments freely flowed through downed trees and incised flow paths where the downed trees were not in contact with the soil surface.

Erosion from simulated concentrated flow remained amplified on burned tree zones in Year 2, but was reduced on burned versus unburned shrub-interspace zones. Burned tree zones in Year 2 generated 5- and 20-fold greater runoff and erosion from the combined $15-45 \mathrm{~L} \cdot \mathrm{min}^{-1}$ concentrated flow releases than unburned tree zones (Table 5). In contrast, Year 2 cumulative erosion on shrub interspaces for 30 and $45 \mathrm{~L} \cdot \mathrm{min}^{-1}$ releases were 7 - to 15 -fold less for burned than unburned conditions. The well-distributed herbaceous cover on burned shrub interspaces in Year 2 likely reduced the detachment and transport capacity of concentrated flow. The cover differences resulted in negligible flow path incision on burned shrub interspaces and an average incision of $43 \mathrm{~cm}^{2}$ cross-sectional area on unburned shrub interspaces. The high erosion rates and flow path incision on unburned shrub-interspace plots demonstrated surface soils in the intercanopy were highly vulnerable to detachment and entrainment by concentrated flow. Burned plot responses clearly show fire amplified erosion potential from tree zones and that the recruitment of intercanopy perennial grass and forb cover over two growing seasons postfire reduced effectiveness of concentrated flow to detach and transport intercanopy soil.

\section{DISCUSSION}

Erosion rates in this study corroborate results from recent Great Basin companion studies that found Phase II-III woodland encroachment into Great Basin sagebrush steppe promotes substantial soil loss from shrub-interspace zones (Pierson et al. 2010). Unburned plots had a high density of dead shrubs at the Castlehead site and extensive bare ground in the intercanopy, indicative of late succession woodland encroachment and site degradation (Table 1; Miller et al. 2005; Tausch and Hood 2007; Miller et al. 2008). Limited ground cover in the intercanopy facilitated weak soil stability (Table 3), promoted rapid runoff (Fig. 3), and generated high levels of soil loss from high-intensity rainfall (Fig. 3) and concentrated flow (Table 5) simulations. Pierson et al. (2010) conducted the same rainfall simulation experiments at a single-leaf pinyonUtah juniper woodland (P. monophylla Torr. and Frém-J. Osteosperma [Torr.] Little) and a Utah juniper (J. Osteosperma [Torr.] Little) woodland in the Great Basin. Large-plot wet-run rainfall simulations in shrub-interspace zones in those studies generated $222 \mathrm{~g} \cdot \mathrm{m}^{-2}$ and $296 \mathrm{~g} \cdot \mathrm{m}^{-2}$, respectively, similar to shrub-interspace results at Castlehead $\left(272 \mathrm{~g} \cdot \mathrm{m}^{-2}\right)$. This study (Fig. 6) and Pierson et al. (2010) measured increasing rates of erosion with increasing plot scale for the intercanopy, indicating the three Phase II-III woodland sites were highly erodible and vulnerable to accelerated runoff and erosion due to well-connected bare-intercanopy area. Results from these three sites support earlier work from pinyon-juniper sites in the Desert Southwest, United States, that found increasing erosion as a function of scale when bare, intercanopy areas were well connected (Wilcox et al. 1996; Davenport et al. 1998; Reid et al. 1999).

Our results in context with literature suggest an intercanopy erosion threshold exists near $60 \%$ bare ground in Great Basin woodlands. Erosion under high intensity rainfall in this study increased exponentially with small increases in bare soil and rock cover beyond $60 \%$ (Fig. 5). A companion study by Pierson et al. (2010) found runoff and erosion from untreated shrubinterspace zones were linearly related and increased exponentially when bare ground exceeded 50-60\% (Fig. 5). These findings are consistent with others from rangeland literature 


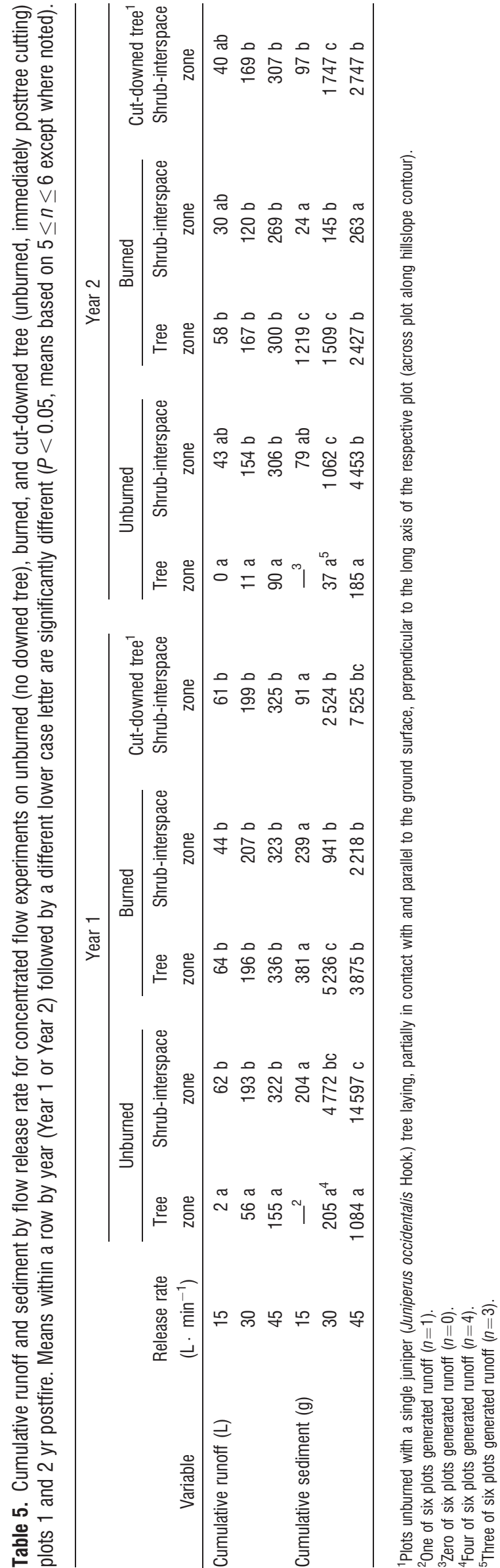

that suggest a ground cover of $50-60 \%$ is necessary to protect surface soils from raindrop and flow detachment (Gifford 1985; Pierson et al. 2008a, 2009). Litter mats on juniper coppices in this study facilitated strong soil water repellency, but provided surface protection from raindrop impact, storage of rainfall, and enhanced infiltration through breaks in the repellent layer (Meeuwig 1971; Madsen et al. 2008; Pierson et al. 2008b; Robinson et al. 2010). In contrast, bare ground in interspaces caused rapid runoff generation and generated substantial wet-run soil erosion across small-plot to large-plot scales (Fig. 6B). Integrating high infiltration rates from shrub coppices with low interspace infiltration rates buffered dry-run runoff from shrub-interspace zones. However, the higher wet-run intensity applied to the sparsely vegetated shrub interspaces generated considerable runoff and erosion. These results suggest sagebrush steppe restoration efforts aimed at improving infiltration and reducing surface erosion over large scales should focus on developing at least 50\% ground cover of litter and vegetation in shrub-interspace zones.

The results from burned plots suggest burning may result in a short-term elevated erosion potential, but a longerterm reduction in erosion relative to unburned sites. Fire removal of cover on juniper coppices amplified erosion rates that persisted $2 \mathrm{yr}$ postfire (Table 3; Fig. 3). Infiltration, however, was improved on interspace small plots within $1 \mathrm{yr}$ of the fire and soil loss returned to prefire conditions by Year 2 (Table 3). The Year 1 effect on tree coppices aggregated over the large-plot scale was a more than 20-fold increase in tree zone erosion. The flush of forb growth on burned shrub interspaces 1 yr postfire was enough to reduce soil erosion from concentrated flow (Table 5). Two years postfire concentrated flow erosion was similar between burned shrub interspaces and unburned tree zones, but remained elevated on burned tree zones. These results suggest gradual recovery of the understory following burning reduces shrub-interspace erosion. Burning in this study was the result of a severe wildfire in a densely stocked, Phase II-III woodland. Burning woodlands at an earlier stage of encroachment or under different conditions may result in a less severe burn, greater amount of postfire vegetation, and/or more rapid postfire ground cover recruitment (Bates et al. 2006; Bates and Svejcar 2009; Bates et al. 2011). Although exposure would be high in the immediate postburn period, hydrologic vulnerability may be reduced over the long-term if sagebrush steppe vegetation recruitment is successful (Bates and Svejcar 2009; Bates et al. 2011). One should consider the potential for annual grass invasions when evaluating prescribed fire options (Bates et al. 2006). Conversion of a woodland encroached site to an annual grassland would potentially increase soil loss over the long term due to increased spatial and temporal vulnerability associated with an increased frequency of burning (Pierson et al. 2011). Annual grass cover by cheatgrass (Bromus tectorum L.) in this study was $2 \%$ prefire and $5 \% 2 \mathrm{yr}$ postfire. Sites with warmer and drier annual soil temperature and moisture regimes than Castlhead may be more susceptible to postfire cheatgrass 
expansion (Barney and Frischknecht 1974; Koniak 1985; Miller et al. 2005).

The effects of soil water repellency on runoff generation and postfire plant recruitment should be considered when assessing the utility of fire for restoring woodland-encroached sagebrush communities. Intense woodland fires can remove as much as $100 \%$ of the overstory and understory vegetation where tree densities facilitate crown fires. In this study, fire removal of the tree canopy and litter over water repellent soils reduced infiltration and amplified runoff (Table 4; Fig. 3). The less than $60 \%$ wetted area at $0-6-\mathrm{cm}$ depth following Year 1 dryrun rainfall simulations on burned juniper coppices and concurrent $40 \%$ reduction in infiltration demonstrate the negative effects of water repellency on soil water recharge. Soil water repellency underneath woodland tree canopies is common, often extends slightly beyond the canopy drip line, and is persistent in the first few years postfire (Lebron et al. 2007; Madsen et al. 2008; Robinson et al. 2009; Madsen et al. 2011). Recent research by Madsen et al. (2011) found persistent soil water repellency postfire reduces water availability for plants and negatively affects plant recruitment in burned tree zones. Herbaceous cover recruitment on burned juniper coppice plots lagged behind that of shrub coppice and interspace small plots throughout this study (Table 3) and soil water repellency effects on infiltration persisted $2 \mathrm{yr}$ postfire (Fig. 2; Table 4). Higher burn temperatures on juniper coppice plots than in the intercanopy may have consumed seed sources and induced mortality of herbaceous cover (Rau et al. 2007; Allen et al. 2008; Bates et al. 2011). However, high burn temperatures would have also occurred underneath shrubs, where postfire plant recruitment was reasonably rapid. Soils underneath shrubs were wettable and had high infiltration rates for unburned and burned conditions (Table 4). We opine that the delayed herbaceous recruitment on burned juniper coppices was at least partially related to persistent hydrophobic conditions and poor infiltration. Our results are consistent with the findings of Madsen et al. (2011) and suggest postfire rehabilitation of burned tree coppice areas may require aggressive reseeding strategies (e.g., Madsen et al. 2012a, $2012 \mathrm{~b}$ ) and average or above average precipitation in the immediate postfire period.

The effects of cutting and immediately placing cut trees across shrub-interspace zones in this study had no effect on large-plot scale runoff and erosion, but tree cutting may reduce hydrologic and erosion vulnerability over time. We observed some dispersal of concentrated flow as it passed through the downed tree material, but high velocity flow tended to route underneath downed trees where the tree material was not in contact with the soil surface. Pierson et al. (2007) found shrubinterspace zones in a western juniper site that had been cut 10 yr earlier had substantial forb and perennial grass recruitment that, along with downed tree material, protected surface soils from raindrop impact and promoted infiltration of artificial rainfall. Erosion from concentrated flow experiments in the Pierson et al. (2007) study were ninefold higher for shrub interspaces in an uncut woodland than those in the 10 -yr-old cut woodland. Cline et al. (2010) found 1-yr-old masticated tree debris promoted infiltration of and reduced erosion from artificial rainfall $\left(102 \mathrm{~mm} \cdot \mathrm{h}^{-1}, 45 \mathrm{~min}\right)$ applied to interspaces $\left(0.5 \mathrm{~m}^{2}\right.$ plots $)$ in a Utah juniper woodland. Cut-tree treatments in this study resulted in only minor amounts of cut-tree contact with the soil surface and no improvements in erosion rates from concentrated flow experiments. The studies by Cline et al. (2010) and Pierson et al. (2007) both suggest mechanical tree treatments can improve infiltration and reduce soil loss by either increasing soil surface protection by tree litter or promoting understory productivity (Bates et al. 2000, 2005, 2011). In contrast to prescribed burning or wildfire, the cutdowned tree treatment posed no short-term negative effects on runoff and erosion, however, extensive high-densities of downed trees may pose a fire hazard and mechanical cutting treatments are labor intensive (see Davies et al. 2011).

Land managers should consider site specific erodibility when considering treatments to reduce runoff and erosion from woodland encroached sagebrush sites. Bare ground, soil conditions, and plot slopes were consistent across shrubinterspace plots in two woodlands studied by Pierson et al. (2010) and the Castlehead site in this study. Application of 15$45 \mathrm{~L} \cdot \mathrm{min}^{-1}$ concentrated flow releases at each of the three sites produced highly variable results. The same concentrated flow experiments in shrub-interspace zones in the Pierson et al. (2010) study generated $2236 \mathrm{~g}$ at a Utah juniper site and 1317 $\mathrm{g}$ at a pinyon-juniper site. Erosion from $15-45 \mathrm{~L} \cdot \mathrm{min}^{-1}$ releases in shrub interspaces in this study delivered nearly $20000 \mathrm{~g}$ of erosion in Year 1. Clearly, the three sites exhibit different erodibilities relative to concentrated flow processes. Such inherent differences in site erodibilities may factor in decisions on whether to apply restoration treatments. Sites with low erodibility may not require treatment strictly from an erosion perspective, or if treatment is desired, may be candidates for burning as well as mechanical tree treatments (see Bates and Svejcar 2009; Bates et al. 2011; Davies et al. 2011). In contrast, sites with high soil erodibility may require multiple, lower impact, treatments aimed at establishing an understory before complete removal of trees. Even where erodibility is high, restoration treatments that generate shortterm erosion pulses followed by declines in soil loss are likely more favorable than long-term soil loss and desertification of sagebrush steppe vegetation resulting from severe tree encroachment.

\section{MANAGEMENT IMPLICATIONS}

This study highlights the importance of recruiting and sustaining intercanopy vegetation and ground cover when applying tree-removal restoration treatments in sagebrush steppe. Tree encroachment-induced reductions in sagebrush steppe understory and ground cover can result in amplified soil loss across spatial scales during convective rainfall events due to a shift from rainsplash-sheetflow to concentrated flow as the dominant erosion process. In this study, erosion from simulated rainfall in an untreated Phase II-III woodland increased with increasing plot area largely due to formation of concentrated low within the bare intercanopy. Our results confirm that erosion from untreated woodland-encroached sagebrush sites increases exponentially where intercanopy bare ground exceeds $50-60 \%$ and suggest that intercanopy ground cover decline to $<55 \%$ may serve as an early warning sign of increasing runoff and erosion vulnerability. Runoff and erosion experi- 
ments from the burned woodland in this study suggest wildfire may act to reduce woodland soil loss where burning induces intercanopy herbaceous cover recruitment. Burning of a Phase II-III woodland enhanced herbaceous cover, decreased bare ground connectivity, improved infiltration, and reduced concentrated flow erosion within the intercanopy over the first $2 \mathrm{yr}$ following fire. However, the burned woodland remained vulnerable to high rates of erosion during simulated highintensity storms. The short-term improvements in infiltration and erosion, but persistent hydrologic vulnerability to highintensity storms imply tree removal by burning may create a restoration pathway for woodland-encroached sagebrush steppe that requires 3 or more yr to take effect depending on the rate of vegetation and ground cover recruitment. The cuttree treatment in this study had minimal short-term impact on infiltration and soil loss from the bare intercanopy. Upon cutting, the trees tended to roll into the intercanopy with the main trunk mostly elevated above the ground, stabilized by branches in partial contact with the soil surface. We observed runoff routing through downed trees and incising the soil surface where unobstructed by branch contacts. With time, branches likely give way to gravitational forces, allowing for greater contact of tree branches and the main trunk with the ground surface. The cut-tree experiments demonstrate that tree cutting or thinning methods targeting more immediate reductions of soil erosion should focus on increasing tree debris contact with the ground surface. Our study across unburned, burned, and cut-tree restoration treatments imply the time required to reduce woodland runoff and soil loss posttreatment is highly dependent on the degree to which the treatment method promotes ground surface protection and establishment of herbaceous cover in the intercanopy.

\section{ACKNOWLEDGMENTS}

The authors thank the Bureau of Land Management, Owyhee Field Office, Marsing, ID, USA, for administrative and field support regarding land access and treatments applied in this study. We are grateful for land access and infrastructural support provided by Mike and Jeannie Stanford during our field experiments. We thank Jaime Calderon and Mathew Frisby for assistance with data collection. We thank Ben Rau (Soil Scientist, USDAARS) and the Desert Research Institute, Reno, Nevada, for assistance with processing soil samples. We also thank Bruce Mackey (Statistician, USDAARS) for assistance with components of the statistical analyses.

\section{LITERATURE CITED}

Abrahams, A. D., A. J. Parsons, and J. Wainwright. 1995. Effects of vegetation change on interrill runoff and erosion, Walnut Gulch, southern Arizona. Geomorphology 13:37-48

Al-Hamdan, 0. Z., F. B. Pierson, M. A. Nearing, C. J. Williams, J. J. Stone, P. R. Kormos, J. Boll, and M. A. Weltz. 2012a. Concentrated flow erodibility for physically based erosion models: temporal variability in disturbed and undisturbed rangelands. Water Resources Research 48:W07504. doi:10.1029/ 2011WR011464

Al-Hamdan, O. Z., F. B. Pierson, M. A. Nearing, J. J. Stone, C. J. Williams, C. A. Moffet, P. R. Kormos, J. Boll, And M. A. Weltz. 2012b. Characteristics of concentrated flow hydraulics for rangeland ecosystems: implications for hydrologic modeling. Earth Surface Processes and Landforms 37:157-168. doi:10.1002/esp.2227
Allen, E. A., J. C. Chambers, and R. S. Nowak. 2008. Effects of a spring prescribed burn on the soil seed bank in sagebrush steppe exhibiting pinyon-juniper expansion. Western North American Naturalist 68:265-277.

Barney, M. A., and M. A. FrischkneCht. 1974. Vegetation changes following fire in pinyon-juniper type of west-central Utah. Journal of Range Management 27:9196.

Bates, J. D., K. W. Davies, and R. N. Sharp. 2011. Shrub-steppe early succession following juniper cutting and prescribed fire. Environmental Management 47:468-481.

Bates, J. D., R. F. Miller, and K. W. Davies. 2006. Restoration of quaking aspen woodlands invaded by western juniper. Rangeland Ecology \& Management 59:88-97.

Bates, J. D., R. F. Miller, and T. S. Svejcar. 2005. Long-term successional trends following western juniper cutting. Rangeland Ecology \& Management 58:533541.

Bates, J. D., AND T. S. SveJcaR. 2009. Herbaceous succession after burning of cut and uncut western juniper woodlands. Western North America Naturalist 69:9-25.

Bisdom, E. B. A., L. W. Dekker, and J. F. T. Schoute. 1993. Water repellency of sieve fractions from sandy soils and relationships with organic material on soil structure. Geoderma 56:105-118.

BlackBURN, W. H., AND C. M. Skau. 1974. Infiltration rates and sediment production of selected plant communities in Nevada. Journal of Range Management 27:476480.

Briske, D. D., B. T. Bestelmeyer, T. K. Stringham, and P. L. Shaver. 2008. Recommendations for development of resilience-based state-and-transition models. Rangeland Ecology \& Management 61:359-367.

Cline, N., B. A. Roundy, F. B. Pierson, P. Kormos, and C. J. Williams. 2010. Hydrologic response to mechanical shredding in a juniper woodland. Rangeland Ecology \& Management 63:467-477.

Davenport, D. W., D. D. Breshears, B. P. Wilcox, and C. D. Allen. 1998. Viewpoint: sustainability of pinyon-juniper ecosystems-a unifying perspective of soil erosion thresholds. Journal of Range Management 51:231-240.

Davies, K. W., C. S. Boyd, J. L. Beck, J. D. Bates, T. J. Svejcar, and M. A. Gregg. 2011. Saving the sagebrush sea: an ecosystem conservation plan for big sagebrush plant communities. Biological Conservation 144:2573-2584.

DeBano, L. F. 1981. Water-repellent soils: a state of the art. Berkeley, CA, USA: USDA Forest Service. PSW-GTR-46. 21 p.

DeBano, L. F., D. G. Neary, and P. F. Ffolliott. 1998. Fire's effects on ecosystems. New York, NY, USA: John Wiley and Sons. $352 \mathrm{p}$.

DoerR, S. H., R. A. Shakesby, and L. H. MacDonald. 2009. Soil water repellency: a key factor in post-fire erosion. In: A. Cerda and P. R. Robichaud [EDS.]. Fire effects on soils and restoration strategies. Land reconstruction and management series. Volume 5. Enfield, NH, USA: Science Publishers. p. 197-223.

GIFFORD, C. F. 1985. Cover allocation in rangeland watershed management: a review. In: E. B. Jones and T. J Ward [EDS.]. Watershed management in the eighties: Proceedings of the Symposium sponsored by the Committee on Watershed Management of the Irrigation and Drainage Division of the American Society of Civil Engineers in conjunction with the ASCE Convention; 30 April-1 May 1985; Denver, CO, USA. Denver, CO, USA: American Society of Civil Engineers. p. 2331.

Grossman, R. B., and F. B. Pringle. 1987. Describing soil surface properties-their seasonal changes and implications for management in soil survey techniques. Soil Science Society of America, Special Publication 20:57-75.

Hanson, C. L., and F. B. Pierson. 2001. Characteristics of extreme precipitation and associated streamflow in the Reynolds Creek Experimental Watershed, Idaho. In: Proceedings of the 12th Symposium on Global Climate Change Variations; 14-19 January 2001; Albuquerque, NM, USA. Albuquerque, NM, USA: American Meteorological Society. p. J2.13-J2.16.

Herrick, J. E., J. W. Van Zee, K. M. Havstad, L. M. Burkett, and W. G. Whitford. 2001. Field soil aggregate stability kit for soil quality and rangeland health evaluations. Catena 44:27-35.

Herrick, J. E., W. G. Whitford, A. G. de Soyza, J. W. Van Zee, K. M. Havstad, C. A. SeYBold, And M. Walton. 2005. Monitoring manual for grassland, shrubland, and savanna ecosystems, volume 1: quick start. Las Cruces, NM, USA: USDA-ARS Jornada Experimental Range. $36 \mathrm{p}$. 
Holland, M. E. 1969. Colorado State University Experimental Rainfall-Runoff Facility, Design, and Testing of Rainfall System. Fort Collins, CO, USA: Colorado State University, Colorado State University Experimental Station. Technical Report CER 69-70 MEH. $21 \mathrm{p}$.

Johnson, D. D., AND R. F. Miller. 2006. Structure and development of expanding western juniper woodlands as influenced by two topographic variables. Forest Ecology and Management 229:7-15.

Knick, S. T., D. S. Dobkin, J. T. Rotenberry, M. A. Schroeder, M. W. Vander Haegen, and C. VAN RIPER III. 2003. Teetering on the edge or too late? Conservation and research issues for avifauna of sagebrush habitats. Condor 105:611-634.

KoNIAK, S. 1985. Succession in pinyon-juniper woodlands following wildfire in the Great Basin. Western North American Naturalist 45:556-566.

Lebron, I., M. D. Madsen, D. G. Chandler, D. A. Robinson, 0. Wendroth, and J. Belnap. 2007. Ecohydrological controls on soil moisture and hydraulic conductivity within a pinyon-juniper woodland. Water Resources Research 43:W08422.

littell, R. C., G. A. Milliken, W. W. Stroup, R. D. Wolfinger, and 0. Schabenberger. 2006. SAS for mixed models. Cary, NC, USA: SAS Institute. 814 p.

Ludwig, J. A., B. P. Wilcox, D. B. Breshears, D. J. Tongway, and A. C. Imeson. 2005 Vegetation patches and runoff-erosion as interacting ecohydrological processes in semiarid landscapes. Ecology 86:288-297.

Madsen, M. D., D. G. ChandleR, And J. Belnap. 2008. Spatial gradients in ecohydrologic properties within a pinyon-juniper ecosystem. Ecohydrology 1:349-360.

Madsen, M. D., S. J. KostKa, A. L. InOuYe, and D. L. Zvirzdin. 2012a. Postfiire restoration of soil hydrology and wildland vegetation using surfactant seed coating technology. Rangeland Ecology \& Management 65:253-259.

Madsen, M. D., S. L. Petersen, B. A. Roundy, B. G. Hopkins, and A. G. Taylor. 2012b. Comparison of postfire soil water repellency amelioration strategies on bluebunch wheatgrass and cheatgrass survival. Rangeland Ecology \& Management 65:182-188.

Madsen, M. D., D. L. Zvirzdin, S. L. Peterens, B. G. Hopkins, B. A. Roundy, and D. G CHANDLER. 2011. Soil water repellency within a burned piñon-juniper woodland: spatial distribution, severity, and ecohydrologic implications. Soil Science Society of America Journal 75:1543-1553. doi:10.2136/sssaj2010.0320

Mclver, J. D., M. Brunson, S. Bunting, J. Chambers, N. Devoe, P. Doescher, J. Grace, D. Johnson, S. Knick, R. Miller, M. Pellant, F. Pierson, D. Pyke, K. Rollins, B. Roundy, G. Schupp, R. Tausch, and D. TuRner. 2010. SageSTEP: a region-wide experiment to evaluate effects of fire and fire surrogate treatments in the Sagebrush Biome. Fort Collins, C0, USA: USDA Forest Service. RMRS-GTR-237. 16 p.

MeEUwIG, R. 0. 1971. Infiltration and water repellency in granitic soils. Ogden, UT, USA: USDA Forest Service. IFRES-INT-111. $22 \mathrm{p}$.

MeYer, L. D., AND W. C. Harmon. 1979. Multiple-intensity rainfall simulator for erosion research on row sideslopes. Transactions of the American Society of Agricultural Engineers 22:100-103.

Miller, R. F., J. D. Bates, T. J. Svejcar, F. B. Pierson, and L. E. Eddleman. 2005. Biology, ecology, and management of western juniper (Juniperus occidentalis). Corvalis, OR, USA: Oregon State University Agricultural Experiment Station. Technical Bulletin 152. $82 \mathrm{p}$.

Miller, R. F., S. T. Knick, D. A. Pyke, C. W. Meinke, S. E. Hanser, M. J. Wisdom, and A. L. HILD. 2011. Characteristics of sagebrush habitats and limitations to long-term conservation. In: S. T. Knick and J. W. Connelly [EDS.]. Greater sage-grouse: ecology and conservation of a landscape species and its habitats. Studies in avian biology, vol. 38. Berkeley, CA, USA: University of California Press. p. 145184.

Miller R. F., T. J. Svejcar, and J. R. Rose. 2000. Impacts of western juniper on plant community composition and structure. Journal of Range Management 53:574585.

Millek, R. F., R. J. Tausch, E. D. McArthur, D. D. Johnson, and S. C. Sanderson. 2008. Age structure and expansion of piñon-juniper woodlands: a regional perspective in the Intermountain West. Fort Collins, C0, USA: USDA Forest Service. RMRSRP-69. $15 \mathrm{p}$.

[NRCS] Natural Resources Conservation Service. 2003. Soil survey of Owyhee County area, Idaho. Washington, DC, USA: US Government Printing Office. 809 p.
Pellant, M., B. Abbey, and S. Karl. 2004. Restoring the Great Basin Desert, U.S.A.: integrating science, management, and people. Environmental Monitoring and Assessment 99:169-179.

Petersen, S. L., and T. K. Stringham. 2008. Infiltration, runoff, and sediment yield in response to western juniper encroachment in southeast Oregon. Rangeland Ecology \& Management 61:74-81.

Petersen, S. L., T. K. Stringham, and B. A. Roundy. 2009. A process-based application of state-and-transition models: a case study of western juniper (Juniperus occidentalis) encroachment. Rangeland Ecology \& Management 62:186-192.

Pierson, F. B., W. H. Blackburn, and S. S. Van Vactor. 2007. Hydrologic impacts of mechanical seeding treatments on sagebrush rangelands. Rangeland Ecology \& Management 60:666-674.

Pierson, F. B., C. A. Moffet, C. J. Williams, S. P. Hardegree, and P. E. Clark. 2009. Prescribed-fire effects on rill and interrill runoff and erosion in a mountainous sagebrush landscape. Earth Surfaces Processes and Landforms 34:193-203.

Pierson, F. B., P. R. Robichaud, C. A. Moffet, K. E. Spaeth, S. P. Hardegree, P. E. Clark, AND C. J. Willaams. 2008a. Fire effects on rangeland hydrology and erosion in a steep sagebrush-dominated landscape. Hydrological Processes 22:2916-2929.

Pierson, F. B., P. R. Robichaud, C. A. Moffet, K. E. Spaeth, C. J. Williams, S. P. Hardegree, and P. E. Clark. 2008b. Soil water repellency and infiltration in coarsetextured soils of burned and unburned sagebrush ecosystems. Catena 74:98108.

Pierson, F. B., S. S. Van Vactor, W. H. Blackburn, and J. C. Wood. 1994. Incorporating small scale spatial variability into predictions of hydrologic response on sagebrush rangelands. In: W. H. Blackburn, F. B. Pierson, G. E. Schuman, and R. Zartman [EDS.]. Variability in rangeland water erosion processes. Madison, WI, USA: Soil Science Society of America. Soil Science Society of America Special Publication 38. p. 23-34

Pierson, F. B., C. J. Willams, S. P. Hardegree, M. A. Weltz, J. J. Stone, and P. E. Clark. 2011. Fire, plant invasions, and erosion events on western rangelands. Rangeland Ecology \& Management 64:439-449.

Pierson, F. B., C. J. Williams, P. R. Kormos, S. P. Hardegree, P. E. Clark, and B. M. Rau. 2010. Hydrologic vulnerability of sagebrush steppe following pinyon and juniper encroachment. Rangeland Ecology \& Management 63:614-629.

PrISM Group. 2011. Prism Climate Group, Oregon State University. Available at: http:// www.prism.oregonstate.edu. Accessed 9 September 2011.

Rau, B. M., R. R. Blank, J. C. Chambers, and D. W. Johnson. 2007. Prescribed fire in a Great Basin sagebrush ecosystem: dynamics of soil extractable nitrogen and phosphorus. Journal of Arid Environments 71:362-375.

Reid, K. D., B. P. Wilcox, D. D. Breshears, and L. MacDonald. 1999. Runoff and erosion in a piñon-juniper woodland: influence of vegetation patches. Soil Science Society of America Journal 63:1869-1879.

Robinson, D. A., I. Lebron, R. J. Ryel, and S. B. Jones. 2010. Soil water repellency: a method of soil moisture sequestration in pinyon-juniper woodland. Soil Science Society of America Journal 74:624-634.

SAS InSTITUTE. 2007. SAS system software, release 9.2. Cary, NC, USA: SAS Institute. Schlesinger, W. H., J. F. Reynolds, G. L. Cunningham, L. F. Huenneke, W. M. Jarkell, R. A. VirginIA, AND W. G. Whitforord. 1990. Biological feedbacks in global desertification. Science 247:1043-1048.

TAUSCH, R. J., AND S. Hood. 2007. Pinyon/juniper woodlands. In: S. M. Hood and M. Miller [EDS.]. Fire ecology and management of the major ecosystems of southern Utah. Fort Collins, CO, USA: USDA Forest Service. RMRS-GTR-202. p. 57-71.

Turnbull, L., J. Wainwright, R. E. Brazier, and R. Bol. 2010. Biotic and abiotic changes in ecosystem structure over a shrub-encroachment gradient in the Southwestern USA. Ecosystems 13:1239-1255.

Wilcox, B. P., D. D. Breshears, and C. D. Allen. 2003. Ecohydrology of a resourceconserving semiarid woodland: effects of scale and disturbance. Ecological Monographs 73:223-239.

Wilcox, B. P., J. Pitlick, C. D. Allen, and D. W. Davenport. 1996. Runoff and erosion from a rapidly eroding pinyon-juniper hillslope. In: M. G. Anderson and S. M. Brooks [EDS.]. Advances in hillslope processes. New York, NY, USA: John Wiley and Sons. p. 61-71. 